Anuario da Facultade de Dereito da Universidade da Coruña

Vol. 23 (2019), pp. 151-194

ISSNe: 2530-6324 || ISSN: 1138-039X

DOI: https://doi.org/10.17979/afdudc.2019.23.0.6015

\title{
ANTECEDENTES HISTÓRICOS Y JURÍDICOS DE LA INSTITUCIÓN PROCESAL DE LA SUBASTA JUDICIAL
}

\section{HISTORICAL AND LEGAL BACKGROUND OF THE JUDICIAL AUCTION PROCESS INSTITUTION}

\author{
RUBÉN LÓPEZ PICÓ \\ Investigador. Departamento de Derecho Procesal \\ Universidad de Granada
}

Resumen: Bajo la rúbrica “Antecedentes históricos y jurídicos de la institución procesal de la subasta judicial", recogemos el tratamiento jurídico que esta institución procesal - la subasta judicial - ha recibido a lo largo de la historia. Desde sus orígenes, en el Derecho Romano, hasta la actualidad; atravesando las diferentes etapas integrantes del denominado Derecho Histórico español hasta finalmente alcanzar su realidad jurídica durante los siglos XIX, XX y XXI.

Palabras claves: antecedentes jurídicos, Derecho Romano, Historia del Derecho español, Derecho Procesal, subasta judicial.

Abstract: Under the heading "Historical and legal background of the judicial auction process institution", we collect the legal treatment that this procedural institution - the judicial auction - has received throughout history. From its origins, in Roman Law, until today; going through the different stages of the so-called Spanish Historical Law until finally reaching its legal reality during the nineteenth, twentieth and twenty-first centuries.

Keywords: legal background, Roman Law, History of Spanish Law, Procedural Law, judicial auction.

Sumario: I. LA SUBASTA JUDICIAL EN EL DERECHO ROMANO. 1. Introducción. 2. El procedimiento de las acciones de Ley o Legis Actiones. A. Legis actio per manus iniectionem. B. Legis actio per pignoris capionem. 3. El procedimiento formulario o processum per formulam. A. Bonorum Venditio. B. Distractio Bonorum. 4. El procedimiento extraordinario o cognitio extra ordinem. II. LA SUBASTA JUDICIAL EN EL DERECHO HISTÓRICO ESPAÑOL. 1. EI Derecho histórico español anterior a las Siete Partidas. A. Liber Iudiciorum - libro de los juicios - o Fuero Juzgo. B. Fuero Viejo de Castilla. C. Fuero Real o Fuero del Libro. D. Leyes de Estilo. 2. Las Siete Partidas. 3. El Ordenamiento de Alcalá y las Leyes de Toro. 4. La Nueva y la Novísima Recopilación. III. LA SUBASTA JUDICIAL EN LAS LEYES DE ENJUICIAMIENTO CIVIL. 1. La Ley de 
Enjuiciamiento Civil de 1855. 2. La Ley de Enjuiciamiento Civil de 1881. IV. IDEAS FINALES. BIBLIOGRAFÍA.

\section{LA SUBASTA JUDICIAL EN EL DERECHO ROMANO}

\section{Introducción}

En el estudio de la subasta judicial, como en tantas otras instituciones, somos deudores de la cultura jurídica romana. El término subasta judicial no es una creación del derecho moderno sino más bien todo lo contrario, un concepto superviviente del Derecho romano antiguo ${ }^{1}$. Es en Roma dónde se sitúa el origen histórico de este concepto jurídico, procedente de la expresión latina sub hasta — bajo la lanza—, ya que, para poder realizar la subasta judicial — subhastatio - era necesario colocar una lanza o pica — símbolo de la propiedad quiritaria ${ }^{2}$ — en el lugar exacto donde iba a tener lugar la venta o enajenación del bien en pública subasta, y junto a la lanza o pica la orden sub hasta venderé - vender lo que está marcado por la lanza-. Fruto de esta expresión, posteriormente surgió el verbo latino subhastare - vender el bien marcado por la lanza ${ }^{3}-$.

La subhastatio romana, al igual que sucede en el actual ordenamiento jurídico español, constituyó una institución procesal inmersa dentro del procedimiento civil romano, y de forma más concreta, dentro de su fase de ejecución. Lo que, a la hora de abordar su estudio, se traduce en la necesidad de analizar las características de esta misma institución en cada uno de los distintos sistemas procesales que estuvieron vigentes en cada una de las diferentes etapas políticas por las que atravesó el Imperio Romano de Occidente hasta su definitiva caída en el año 476: el procedimiento de las acciones de ley o legis actiones - desde los orígenes de la ciudad de Roma hasta la mitad del Siglo II a.C.- ; el procedimiento formulario o per formulam — desde la mitad del Siglo II a.C., con la elaboración de la Lex Aebutia, hasta el Siglo III d.C., coincidiendo con el mandato del emperador Diocleciano-; y el procedimiento extraordinario o cognitio extra ordinem - desde el Siglo III d.C. hasta fases previas al fin del Derecho Romano-. En cada uno de esos tres sistemas procesales, encontramos la presencia de la subasta judicial como un instrumento de enajenación forzosa asociada a la fase ejecutiva del procedimiento civil romano, pero con unas características propias, que la diferencian de la subasta judicial existente en el resto de los sistemas procesales, anteriores y posteriores ${ }^{4}$.

A su vez, estos tres grandes sistemas procesales quedaron agrupados en dos grandes órdenes procesales. El primero de ellos, el sistema de los juicios privados -

\footnotetext{
${ }^{1}$ PRIETO-CASTRO Y FERRÁNDIZ, L., Derecho Procesal Civil. $3^{\text {a }}$ ed. Ed. Tecnos, Madrid, 1979, p. 194.

2 TOMÉ PAULÉ, J., "La subasta judicial en el Derecho histórico español”. Boletín Mexicano de Derecho Comparado. Ed. Gobierno de México, México, 1975, p. 1039.

${ }^{3}$ MORAL MORO, M ${ }^{\mathrm{a}}$.J., La subasta judicial de bienes inmuebles. Ed. Bosch, Barcelona, 2000, p. 57.

${ }^{4}$ IGLESIAS SANTOS, J., Derecho Romano. $16^{\mathrm{a}}$ ed. Ed. Ariel, Barcelona, 2007, p. 117.; CAMACHO

EVANGELISTA, F., Derecho privado romano. $2^{\mathrm{a}}$ ed. Ed. Técnica Avicam, Granada, 2016, p. 115.
} 
Ordo Iudiciorum Privatorum - comprendía el sistema procesal de las legis actiones acciones de ley - y el sistema procesal per formulam — procedimiento formulario-. Por su parte, el segundo, recogía únicamente el sistema procesal de la denominada cognitio extra ordinem — procedimiento extraordinario ${ }^{5}$ -

\section{El procedimiento de las acciones de Ley o Legis Actiones}

En la época primitiva del Derecho Romano, tuvo lugar el desarrollo de la denominada Lex Duodecim Tabularum — Ley de las XII Tablas _ _, dónde ya existía algún medio de ejecución, de tipo personal y no patrimonial. Concretamente en la Tabla III se recogía el denominado procedimiento de la manus iniectio, precedente de la posterior legis actio per manus iniectionem —acción de ley por imposición de la $\operatorname{mano}^{7}$ -

Pese a que la llegada de la época clásica supuso la apuesta por la institución del iudicium — juicio_- basada en el officium de particulares o árbitros — ante la falta de la acción estatal, el arbitraje constituía el único medio para la resolución de los litigios-, no es hasta la aparición del denominado procedimiento de las legis actiones ${ }^{8}$-acciones de ley - cuando la justicia queda por primera vez bajo la dirección y control de la autoridad estatal. Pasando de ese modo, de una antigua concepción sacra a una moderna secularización, en la que la solución de la controversia interpartes se encomendaba a la decisión racional de un juez'.

El procedimiento de las legis actiones —entendiendo por actiones cada una de las declaraciones solemnes del propio Derecho realizadas por las partes o por una de ellas ante el Tribunal del Magistrado ${ }^{10}$ — constituyó la forma más antigua de enjuiciar usada exclusivamente por los ciudadanos romanos para reclamar el reconocimiento de un derecho existente y previamente ya reconocido por el Ius Civile Romanorum, así como para la resolución de las controversias acaecidas en la ciudad de Roma o dentro de su primera milla, fuera de los límites de la civitas. Este procedimiento de las legis actiones representaba el imperio de la forma; una forma angosta y embarazosa, embutida de rito y solemnidad, dónde las partes presentes in iure -ante el magistrado - hacían sus peticiones y declaraciones de acuerdo a fórmulas orales,

\footnotetext{
5 IGLESIAS REDONDO, J., Derecho Romano. Historia e Instituciones. $18^{\mathrm{a}}$ ed. Sello Editorial, Barcelona, 2010, p. 133.

${ }^{6}$ La Lex Duodecim Tabularum - Ley de las XII Tablas - es considerada como el primer código del Derecho Romano, constituyendo pues la base del Derecho Romano y el "punto de partida" de todo el derecho moderno. Estas tablas realizadas en madera blanca, fueron destruidas tras la invasión de los galos en el año 383 a.C. coincidiendo con el mandato del rey galo Bruno. A pesar de su destrucción, los preceptos contenidos en ellas nunca fueron derogados formalmente, lo que permitió que en una etapa posterior fueran reconstruidas en bronce y fijadas de nuevo en el Foro de la ciudad de Roma, a la vista de todos. GARCIA ESCOBAR, G.A. "El tratamiento de los créditos concursales y el principio de la par conditio creditorum". Revista Internacional de Doctrina y Jurisprudencia. N ${ }^{\circ}$ 5, pp. 1-31. Ed. Universidad de Almería, Almería, 2014, pp. 1-31.

7 GARCÍA GARRIDO, M.J., Derecho Privado Romano. Casos-Acciones-Instituciones. 20 ${ }^{\mathrm{a}}$ ed. Ed. Ediciones Académicas, Madrid, 2015, p. 61.

8 "Las legis actiones constituían actuaciones solemnes que realizadas de forma verbal ante el magistrado mediante la utilización de palabras rituales — certis verbis - implicaban en sí mismas el establecimiento de una afirmación vinculante”. FUENTESECA, P., Derecho Privado Romano. Ed. Gráficas E. Sánchez, Madrid, 1978, p. 49.

${ }^{9}$ D’ORS J.A., Derecho Privado Romano. 10 a ed. Ed. Eunsa, Pamplona, 2004, p. 124.

10 SCIALOJA, V., Procedimiento civil romano. Ediciones Jurídicas Europa-América, Buenos Aires, 1954, p. 95.
} 
rigurosas y solemnes que habían sido establecidas por la costumbre y la ley, necesarias para evitar la pérdida del litigio ${ }^{11}$.

El procedimiento de las legis actiones junto al procedimiento per formulam que más adelante estudiaremos - tenían como característica principal en común su bipartición en dos fases: una primera, in iure - ante el magistrado - y una segunda, apud iudicem - ante el juez privado designado por las partes-.

La fase in iure, comenzaba con la citación que el propio actor realizaba al demandado ${ }^{12}$ - in ius vocatio - para, en presencia del magistrado, conocer el objeto de la controversia y resolver las cuestiones que pudiesen surgir de forma previa al inicio del procedimiento: competencia del magistrado, legitimación de las partes, ausencia de cosa juzgada, admisibilidad y adecuación de la controversia, y la no inmersión de la regla del non bis in idem. Si el magistrado atisbaba el incumplimiento de alguna de estas cuestiones previas, denegaba la autorización necesaria para incoar el procedimiento, pero si por el contrario, consideraba que todas ellas se cumplían, autorizaba a las partes enfrentadas para el desarrollo de los ritos, la realización de los gestos y el pronunciamiento de las fórmulas verbales oportunas, dependiendo de las características propias de la acción que se pretendía ejercer. Desembocando finalmente en la petición de acción — editio actionis - y su concesión, o no, por el magistrado dare o denegare actionem ${ }^{13}$ -

Si finalmente el magistrado concedía al actor la acción previamente solicitada por él, el inicio del procedimiento tenía lugar cuando las partes —en presencia del magistrado y de testigos bajo juramento - presentaban sus argumentos, exponían los puntos de la controversia que les enfrentaba — patentando la naturaleza del derecho alegado cuya protección se invocaba - y se proveían del nombramiento del juez privado - iudex - sobre la base de un contrato arbitral que implicaba la aceptación por ellas mismas de la decisión que el iudex finalmente emitiese - litis contestatio- - Todo ello, nuevamente, bajo los correspondientes formalismos orales y solemnes, variables en función de la acción a ejercer.

11 Tal era la exigencia, que los litigantes ajenos al secreto de esas fórmulas jurídicas, antes de iniciar el pleito, necesitaban acudir a los sacerdotes — primeros juristas de la Roma Antigua y únicos conocedores de esas fórmulas - para recibir de ellos el necesario asesoramiento jurídico. ARANGIO RUIZ, V., Instituciones de Derecho Romano. Ed. Depalma, Buenos Aires, 1986, p. 124. Una muestra de la exigencia antes señalada, es el famoso caso narrado por GAYO -4,11-. conforme al cual una vez que habían cortado unas vides, su propietario, con el fin de obtener la obligada indemnización, se dirigió, como procede, al Colegio de los Pontífices — donde se conservaban las fórmulas procesales - para que le instruyeran jurídicamente. En la declaración jurídica que los pontífices le prepararon, se encontraban las palabras típicas del delito, o sea, poco más o menos: "afirmo que tú has cortado, furtivamente, árboles de mi fundo...". Sin embargo, una vez en presencia del magistrado, el demandante, cuyo pensamiento evocaba su propia desgracia, cambió la palabra árboles por la de vides, lo que motivó que le fuera denegada la acción solicitada. ORTEGA CARRILLO DE ALBORNOZ, A., Derecho Privado Romano. Ed. Ediciones del Genal, Málaga, 2010, p. 69.

12 Frente al requerimiento del demandado por el demandante a comparecer ante el magistrado, tres eran las posibles actitudes que el demandado podía adoptar: acudir ante el magistrado, solicitar el aplazamiento de su comparecencia - debiendo simultáneamente en este caso hacer una promesa de futura comparecencia (vadimonium romano), o garantizar su futura comparecencia mediante un vas (aquél que se ofrecía en garantía de la comparecencia de otro)-, y negarse a comparecer, pudiendo el actor conducirlo por la fuerza - manus iniectio - ante el magistrado. CASINOS MORA, F.J., Derecho Privado Romano. Ed. Dykinson, Madrid, 2016, p. 193.

${ }^{13}$ FERNÁNDEZ DE BUJÁN, A., Jurisdicción y Arbitraje en Derecho Romano. Ed. Iustel, Madrid, 2006, p. 77. 
La segunda fase, apud iudicem, arrancaba con el inicio de la intervención del juez privado que previamente había sido designado por los litigantes a fin de dirimir la controversia existente entre ellos. El juez privado, al no ser magistrado ni autoridad judicial sino un jurista encargado de dar una opinión o emitir una sentencia — parare sententia-, actuaba únicamente conforme a la potestad que le había sido otorgada para juzgar la controversia — potestas iudicandi - . Ordenando así, la práctica de la prueba ${ }^{14}$ y el dictado de la sentencia - decretum o mandatum - por la que se ponía fin a la controversia existente entre las partes enfrentadas, revestida ésta última de la iurisdictio o imperium - entendida como el conjunto de facultades atribuidas únicamente a los magistrados para la administración de la justicia civil. A partir del siglo III d.C., y con ciertos límites, también la criminal - que emanaba del magistrado in iure ${ }^{15}$. Si el juez privado no dictaba sentencia por falta de conocimiento claro sobre la forma en la que se debía resolver la controversia interpartes —iurare rem sibi non liquere-, el magistrado procedía al nombramiento de un nuevo juez privado - mutatio iudicis - encargado de dar solución a esa misma controversia interpartes mediante la emisión de la correspondiente sentencia.

Dictada la sentencia — absolutoria o condenatoria- que ponía fin a la controversia interpartes, ésta se exponía de forma oral y pública por el juez privado ante las mismas partes que previamente lo habían designado. No cabiendo contra ella recurso alguno, y adquiriendo la controversia resuelta a través de ella el carácter de cosa juzgada $^{16}$.

De acuerdo con $\mathrm{GAYO}^{17}$, cinco eran las legis actiones: legis actio per sacramentum —acción de ley por puesta sacramental-, legis actio per iudicis postulationem - acción de ley por petición del juez-, legis actio per condictionem acción de ley por emplazamiento-, legis actio per manus iniectionem —acción de ley por imposición de la mano-, y legis actio per pignoris capionem - acción de ley por toma de prenda - Mientras las tres primeras estaban encaminadas al procedimiento de cognición, es decir, a la declaración o transformación a través de una sentencia de derechos ya existentes - reclamación de las cantidades debidas-; las dos últimas, se encontraban orientadas al procedimiento de ejecución, tratando de dar efectividad a los derechos reconocidos en una sentencia, previamente dictada por el juez privado, resultado del ejercicio por el interesado de la correspondiente legis actiones obtención del cobro-.

Finalizado el procedimiento civil romano con la emisión de la sentencia por el juez privado - parare sententia - , por la que se estimaba o desestimaba la pretensión del actor, ante su incumplimiento voluntario por el condenado en ella, el interesado podía obtener su ejecución recurriendo al procedimiento de las legis actiones, y más

\footnotetext{
${ }^{14}$ La práctica de la prueba reparaba en las siguientes notas: la carga de la prueba correspondía a las partes -onus probandi-, debía recaer sobre los hechos alegados por éstas, y desarrollarse conforme al principio dispositivo y de libre valoración de la prueba, fundamentos de la actuación del juez. PANERO GUTIÉRREZ, R., Epítome de Derecho Romano. Ed. Tirant Lo Blanch, Valencia, 2010, p. 170.

15 ÁlVAREZ SUÁREZ, U., Curso de Derecho Romano, Tomo I. Introducción, Cuestiones Preliminares, Derecho Procesal Civil Romano. Ed. Revista de Derecho Privado, Madrid, 1955, pp. 185-187.

${ }^{16}$ FERNÁNDEZ DE BUJÁN, A., Jurisdicción y Arbitraje en Derecho Romano. Op., Cit., p. 18.

${ }^{17}$ GAYO, Instituciones jurídicas. Editorial Iberia S.A. Barcelona, 1965, comentario IV, 12, p. 142.
} 
concretamente, a través del ejercicio de la legis actiones per manus iniectionem y de la legis actiones per pignoris capionem ${ }^{18}$.

\section{A. Legis actio per manus iniectionem}

La legis actio per manus iniectionem —acción de ley por imposición de la mano-, al ser una acción de carácter ejecutivo, permitía proceder contra la persona del deudor a fin de prenderlo para que hiciese frente al cumplimiento de sus obligaciones, generalmente consistentes en el pago de una deuda económica. De ese modo, para poder ejercer esta acción, era necesario que de forma previa existiese una sentencia emitida por el iudex, en la que de forma exacta se determinase la cantidad que se debía y quedase recogida la obligación de hacer frente al pago de la misma — summa condemnationis $^{19}$-.

Pese a ello, posteriormente, otras leyes permitieron — para la ejecución de ciertas obligaciones - el ejercicio de la manus iniectio sin que fuese necesaria la existencia de una sentencia previa dictada por el iudex, en la que de forma exacta se recogiese la cantidad debida así como la obligación de hacer frente al pago de la misma - manus iniectio pro iudicatus —, tratándose así de una manus iniectio de carácter privilegiada. Los créditos privilegiados que disponían de dicha fuerza ejecutiva eran los siguientes $^{20}$ :

- Los créditos existentes contra el confessus - in iure confeso-, del que se decía que pro iudicato habetur era tenido por condena.

El crédito del fiador contra el deudor principal cuando en el plazo de seis meses no le hubiese reembolsado la cantidad que previamente había pagado por él, en su nombre. Otorgada por la Lex Publilia.

El crédito del fiador contra el acreedor cuando siendo varios los fiadores, el acreedor haya exigido de aquél mayor parte del que le correspondía. Otorgada por la Lex Furia de Sponsu.

- Los créditos impuestos a un heredero derivados de un legado, o en general quien por causa de muerte hubiese sido obligado a pagar más de los mil ases ${ }^{21}$.

- Los créditos del prestatario contra el prestamista para obtener la devolución de los intereses excesivos que le hubiese pagado.

El procedimiento de la legis actio per manus iniectionem se desarrollaba de la siguiente forma: pasados treinta días desde que se dictó la sentencia condenatoria por el iudex, ante el incumplimiento voluntario de la misma por el condenado - iudicatus-,

\footnotetext{
18 Junto con estas legis actiones ejecutivas de carácter digamos principal, existían otras de carácter secundario, pero igualmente efectivas. Entre ellas, se encontraban: la legis actio per sacramentum in personam, orientada a reclamar a los deudores el cumplimiento de sus obligaciones, la legis actio per iudicis arbitre postulationem, para la reclamación de los créditos procedentes de un contrato verbal, y la legis actio per condictionem, que en realidad era una acción abstracta destinada a que el acreedor pudiese reclamar una cantidad de dinero determinada sin la necesidad de manifestar la causa de su reclamación. ROBLES VELASCO, L.M., Unidades didácticas de Derecho Romano Privado. $2^{\mathrm{a}}$ ed. Ed. Editorial Técnica Avicam, Granada, 2015, pp. 227-230.

${ }^{19}$ LUQUE TORRES, G., Las subastas judiciales: aspectos civiles, procesales e hipotecarios. Ed. Comares, Granada, 1999, p. 9.

${ }^{20}$ RASCÓN GARCÍA, C., Sintesis de Historia e Instrucciones de Derecho Romano. $4^{\mathrm{a}}$ ed. Ed. Tecnos, Madrid, 2011, pp. 188-189.

${ }^{21}$ Moneda acuñada por la autoridad romana que hacía las veces de impuesto directo instituido durante la República Romana.
} 
el interesado tenía la posibilidad de llevarlo ante el magistrado, y ante él, mientras le ponía su mano encima - de ahí la denominación de esta acción "por imposición de la mano"- ejercer la legis actio mediante la pronunciación de la fórmula solemne "Cómo has sido juzgado y condenado a pagarme el valor de diez mil sestercios, puesto que no has pagado, por este asunto te aprehendo por la cadena de diez mil sestercios" 22 .

Manifestadas estas palabras solemnes, y ante la imposibilidad de oposición por el condenado a las mismas, la única opción de la que éste último disponía para tratar de evitar la manus iniectionem pasaba por el pago de la cantidad debida, bien por él mismo, bien por una tercera persona - vindex ${ }^{23}$ - , que debía tener la misma condición que el condenado. Cuando el vindex hacía frente al pago de la cantidad debida por el iudicatus, éste último quedaba automáticamente liberado de la aprehensión corporal y de toda responsabilidad jurídica, al tiempo, que el vindex se situaba en la posición del deudor y se subrogaba en su obligación ${ }^{24}$.

Ante la insolvencia económica del iudicatus, y la inexistencia de un vindex que pudiese hacer frente al pago de la deuda, el pretor - a merced de su imperiumautorizaba la ejecución del derecho del acreedor — manus iniectio - sobre la propia persona del deudor con el término addico ${ }^{25}$, quedando de este modo el acreedor facultado para trasladar al addictus — deudor sobre el que recaía la manus iniectiohasta su casa y tenerlo atado en ella con cadenas de hasta un peso máximo de treinta libras. Esta situación tenía una duración máxima de hasta sesenta días, durante los cuales, el acreedor llevaba al addictus al foro durante tres días de mercado consecutivos - trinundinum - gritando el importe de la deuda con el objetivo de que un tercero ajeno al addictus - decidiese intervenir en su favor pagando lo que debía. Si transcurrido esos sesenta días nada de lo descrito ocurría, el acreedor podía decidir entre vender al addictus como esclavo Trans Tiberim, es decir, fuera de la ciudad de Roma, o darle muerte. Cuando los acreedores eran varios, y optaban por darle muerte, disponían de la posibilidad de repartirse su cadáver en trozos — partes secare. Ley de las XII Tablas ${ }^{26}$ -

\footnotetext{
22 "Quod tu mihi iudicatus sice damnatus es sextertium x milla, quandoc non solvisti, ob eam rem ego tivi sextertium x milium iudicati manum inicio". GAYO, 4,21.; CASINO MORA, F.J., Derecho Privado Romano. Op., Cit., p. 201.

${ }^{23}$ El vindex, al subrogarse en la posición del demandado y hacer frente al pago de la cantidad que éste debía, asumía de forma adicional la obligación de demostrar en un nuevo proceso judicial la invalidez de la sentencia del iudex que condenaba al iudicatus. En caso de no lograrlo, el vindex era condenado al pago del doble del importe que se le exigía al iudicatus en la sentencia - litis crescencia-. Si era necesario, el acreedor podía iniciar contra el vindex una nueva manus iniectio ejecutiva, a fin de obtener el cobro del crédito debido. IGLESIAS REDONDO, J., Derecho Romano. Historia e Instituciones. $18^{\mathrm{a}}$ ed. Op., Cit., p. 145.

${ }^{24}$ ARIAS RAMOS, J. y ARIAS BONET, J.A., Derecho Romano, Tomo I. $18^{\mathrm{a}}$ ed. Ed. Revista de Derecho Privado, Madrid, 1986, p. 179.

${ }^{25}$ El término addico comprendía aquellos actos que atribuían derechos constitutivos a favor de una de las partes que actuaba en el procedimiento, consistiendo así, en el pronunciamiento del magistrado que sancionaba lo actuado por las partes o por una de ellas. Junto con el do y el dico, constituía la denominado tria verba solemnices expresión de la iurisdictio del magistrado. Mientras la palabra Do era con la que comenzaba la actuación del magistrado, en aquellos casos en los que previamente se había establecido un procedimiento. Por su parte, la palabra Dico - proveniente del verbo latino Dicereexpresaba toda aquella actuación del magistrado con incidencia directa sobre el desarrollo del litigio. TORRENT RUIZ, A.J., Manual de Derecho Privado Romano. Ed. Edifoser S.L., Zaragoza, 2002, pp. 115-116.

${ }^{26}$ CAPILLA RONCERO, F., La responsabilidad patrimonial universal y el fortalecimiento de la protección del crédito. Ed. Fundación Universitaria de Jerez, Jerez, 1989, p. 130.
} 
Sin embargo, más tarde, a través de la Lex Poetelia Papiria del año 326 a.C., se prohibió la venta y ejecución del deudor insolvente, así como su aprehensión corporal por medio de cadenas y grilletes - non corpus sed bona-. A partir de ese momento, ante este tipo de situaciones, el acreedor podía mantener al iudicatus en su casa y hacerle trabajar hasta que con su trabajo pudiese satisfacer el total de lo debido; pasando así de una responsabilidad de tipo personal a una responsabilidad de tipo patrimonial ${ }^{27}$. Esta derogación de la muerte por deudas, constituye el antecedente de la actual responsabilidad patrimonial universal contenida en el art.1.911 de nuestro Código Civil: "del cumplimiento de las obligaciones responde el deudor con todos sus bienes presentes y futuros".

\section{B. Legis actio per pignoris capionem}

La legis actio per pignoris capionem - acción de ley por toma en prendaconstituía la segunda de las legis actiones que poseían un carácter eminentemente ejecutivo, al tratar de hacer efectivos los derechos ya reconocidos en la sentencia que previamente ya había sido dictada por el juez privado — iudex - resultado del ejercicio de la correspondiente acción por el interesado.

A través de ella, el magistrado, a petición del acreedor -mediante la formulación de ciertas palabras de tradición ritual, GAYO, 4, 29-, ordenaba la ocupación de algunos de los bienes muebles que constituían el patrimonio del deudor, o inmuebles en su defecto, dependiendo de la cuantía a la que ascendiese la deuda. Si transcurridos dos meses desde su ocupación, el deudor no procedía a efectuar el pago de la cuantía reclamada, el magistrado ordenaba la enajenación en subasta judicial del bien o bienes del deudor que habían sido ocupados, entregándolos al postor que ofreciese el mayor precio por ellos. Si nadie se interesaba por la adquisición del bien o bienes subastados - con el objetivo de poder satisfacer el derecho de crédito del acreedor-, éstos le eran entregados al acreedor en pago de su deuda - datio in solutum- Como vemos, la legis actio per pignoris capionem constituía una especia de secuestro judicial del patrimonio del deudor insolvente - al privarlo de los bienes que lo comprendían-, así como el origen de la enajenación en subasta judicial que forma parte de los actuales procedimientos de ejecución forzosa ${ }^{28}$.

Entre las características propias de esta modalidad de legis actio per pignoris capionem, además de señalar su utilización como medio de ejecución patrimonial y no personal - al recaer exclusivamente sobre los bienes muebles e inmuebles ${ }^{29}$ del

\footnotetext{
${ }^{27}$ CAMAChO EVAngelista, F., Derecho Privado Romano. $2^{\text {a }}$ ed. Op., Cit., p. 118. La sustitución definitiva de la responsabilidad personal del deudor por la patrimonial, no tuvo lugar hasta la etapa de Marco Aurelio con la aprobación del Decretum Divi Marci, compuesto por un conjunto de leyes encaminadas a condenar el uso de la violencia para la propia defensa de los derechos mediante el establecimiento de una sanción civil. En virtud de ésta, aquel que ponía en práctica medios de propia defensa o de ejecución sin poseer el correspondiente título jurídico, además de perder su derecho, tenía la obligación de restituir lo exigido por razón del duplo. IGLESIAS SANTOS, J., Derecho Romano. $16^{\mathrm{a}}$ ed, Op., Cit., p. 120.

${ }^{28}$ SCIALOJA, Procedimiento Civil Romano. Op., Cit., p. 298.

${ }^{29}$ FERNÁNDEZ BARREIRO A. y PARICIO, J., Fundamentos de Derecho Patrimonial Romano. Ed. Centro de Estudios Ramón Areces, S.A., Madrid, 1991, p. 54.
} 
deudor-, también podemos destacar su carácter excepcional o privilegiado, al poder ejercitarse únicamente contra determinados créditos impagados ${ }^{30}$ :

- $\quad$ Los créditos de los soldados por su stipendium - aes militares-.

- Los créditos destinados a la compra de caballos, a su manutención - aes equestre y aes hordearium, respectivamente-.

Los créditos destinados a la compra de un animal para posteriormente sacrificarlo ante los dioses — aes hostiarum-.

Precisamente, estas mismas características junto con la posibilidad de proceder a su ejecución sin la necesidad de sentencia previa, ni presencia del magistrado son las que provocaron que la naturaleza jurídica de esta legis actio fuese cuestionada, al dudarse si se trataba, o no, de una auténtica acción de ley. Mientras sus defensores GAYO - se apoyaban en la necesidad de reproducir determinadas palabras solemnes para poder ejercitarla, hay autores como FUENTESECA ${ }^{31}$ que consideraban que no estaban ante una auténtica legis actio sino más bien ante una forma primitiva de preferencia ejecutiva a favor de determinados créditos privilegiados ${ }^{32}$. Pues la toma de la prenda tenía lugar fuera del tribunal, sin la presencia del magistrado y, en multitud de ocasiones, en ausencia también del propio deudor - requisitos esenciales de toda legis actiones-.

\section{El procedimiento formulario o processum per formulam}

La rigidez y el formalismo — nimia subtilitas $^{33}$ - al que estaba sometido el procedimiento de las legis actiones junto a la necesidad de proteger nuevas situaciones y recepcionar el Ius Gentium dentro del Ius Civile Romanorum, motivaron la aparición del processum per formulam — procedimiento formulario ${ }^{34}$ - . Su origen se encuentra pues en el Ius Honorarium, propio de los procedimientos celebrados ante el pretor peregrino - praetor peregrinus - entre ciudadanos romanos $\mathrm{y}$ extranjeros $\mathrm{o}$, únicamente, entre estos últimos. Así, el rígido procedimiento de las acciones de ley, reservado en exclusiva para los ciudadanos romanos, fue sustituido por una fórmula escrita que permitía una mayor adaptación y flexibilidad a las circunstancias de las partes concurrentes en cada caso concreto. A pesar de la convivencia entre ambos sistemas procesales - procedimiento de las acciones de ley y procedimiento formulario- durante aproximadamente cien años, finalmente, el procedimiento de las legis actiones acabó desapareciendo, al ser sustituido por el procedimiento formulario, tras la aprobación de la Lex Ebucia -130 a.C.—, la Lex Aebutia -150 a.C.—, y la Lex Iulia Iudiciorum Privatorum — año 17 a.C., durante la etapa del Emperador Augusto-.

\footnotetext{
${ }^{30}$ ARIAS RAMOS, J. y ARIAS BONET, J.A., Derecho Romano, Tomo I. $18^{\mathrm{a}}$ ed. Op., Cit., p. 184.

31 FUENTESECA, P., Investigaciones de Derecho Procesal Romano. Ed. Studia Iris Romani Salmanticensia, Salamanca, 1969, p. 63.

${ }^{32}$ D’ORS J.A., Derecho Privado Romano. $10^{\mathrm{a}}$ ed. Op., Cit., p. 125.

33 "El procedimiento de las legis actiones, con su rígido formalismo, llevaba aparejados no pocos inconvenientes. Así, la exigencia de observar estrictamente los términos de la ley significaba que un mínimo error o equívoco, al no ser susceptible de repetición o rectificación, podía llevar aparejada la pérdida del pleito. Además, ese rígido formalismo impedía al juez conocer de las circunstancias particulares de las partes en cada caso concreto, lo que le impedía averiguar su verdadera naturaleza". CAMACHO EVANGELISTA, F., Derecho Privado Romano. $2^{\mathrm{a}}$ ed. Op., Cit., p. 128.

${ }^{34}$ Gayo I. 4.30: "Itaque per legem Aebutia et duas Filias sublatae sunt istae legis actiones effectumque est, ut per concepta verba, id est per formulas litigamos". "Y asi estas acciones son abolidas por la Ley Ebucia y las dos Julias, y el efecto es, que litigaremos por palabras escritas - concepta verba-, esto es por fórmulas".
} 
Sustituyéndose, de este modo, la forma oral por la escrita ${ }^{35}$; la certa verba por la concepta verba.

El procedimiento formulario como parte integrante del denominado Ordo Iudiciorum Privatorum, al igual que ocurría en el procedimiento de las legis actiones, también se encontraba dividido en dos fases: una primera, in iure -ante el magistrado - y una segunda, apud iudicem - ante el juez privado-. Pero de forma diferente a lo descrito para el procedimiento de las acciones de ley, en este procedimiento formulario, previamente al inicio de la fase in iure, el actor a través de una comunicación verbal —editio actionis ${ }^{36}$ - informaba al demandado acerca de la petición que iba a formular, el fundamento en el que se apoyaría y las pruebas que pensaba aportar - instrumenta - , para tratar con ello que el demandado hiciese frente al cumplimiento de su obligación, y evitar así el inicio y posterior desarrollo del correspondiente litigio interpartes. Si de esta medida no surgían los efectos esperados, se citaba entonces conforme a las normas del ius vocatio - antes estudiado- al reus demandado - para que compareciese ante el magistrado ${ }^{37}$.

Encontrándose las partes enfrentadas en presencia del magistrado, el demandante exponía sus pretensiones, señalaba la acción que quería hacer valer - editio o postulatio actionis - y solicitaba al magistrado la concesión de la misma. Hecho esto, se daba traslado al demandado para que entre las distinta posturas procesales existentes, escogiese la suya propia: confessio - equivalía al allanamiento del demandado y por tanto el reconocimiento formal de las pretensiones del actor-, indefensio - actitud pasiva del demandado consistente en la no afirmación pero tampoco negación de nada, que en la mayoría de ocasiones se traducía en la atribución de la cosa litigiosa al demandante $\mathrm{o}$ en el reconocimiento de su derecho de crédito-, ius iurandum, transactio, desistimiento, interrogationes y cautiones; siendo la más habitual de todas ellas la de negar o admitir las afirmaciones realizadas por el demandante y sus pretensiones $^{38}$. Tras el análisis del caso — causae cognitio - , el magistrado determinaba si se daba o no la necesidad de proteger jurídicamente la situación descrita, dando o denegando la acción previamente solicitada por el actor -actionem dare o actionem denegare - Finalmente, si la respuesta era afirmativa, se redactaba — por las partes - y aprobada - por el propio magistrado- la fórmula ${ }^{39}$ en la que se indicaba el juez

\footnotetext{
${ }^{35}$ PANERO GUTIÉRREZ, R., Derecho Romano. $4^{\mathrm{a}}$ ed. Ed. Tirant Lo Blanch, Valencia, 2008, p. 154.

${ }^{36}$ De incumplirse el deber del demandante de emitir al demandado el editio actionis, el magistrado concedía contra el actor y a favor del demandado una acción por este hecho, denominada actio in factum. Ibidem, p. 171.

${ }^{37}$ GARCÍA GARRIDO, M.J., Derecho Privado Romano. Casos-Acciones-Instituciones. 20 a ed. Op., Cit., 78 .

38 ORTEGA CARrillo DE AlBornoz, A., Derecho Privado Romano. Op., Cit., p. 77.

39 Las fórmulas eran propuestas de solución al conflicto interpartes que éstas mismas presentaban al magistrado, quién tras su análisis podía aceptarlas o modificarlas, y posteriormente traspasarla al juez privado con la intención de dar inicio a la segunda fase del procedimiento — apud iudicem-. Desde un punto de vista estructural, las fórmulas eran documentos escritos en una doble tablilla de cera, dónde su parte interna y externa recogían el mismo texto, si bien, la parte interna además se encontraba sellada por las partes y por los testigos ante el magistrado. Su contenido se encontraba dividida en dos partes: la ordinaria - aquélla que normalmente se encontraba en todas las fórmulas - y la extraordinaria o accesoria - aquélla que podía agregarse a cualquier fórmula-, y siempre estaba encabezada por el nombramiento del juez elegido por las partes para la solución del conflicto. Mientras la parte ordinaria estaba compuesta por el intentio - expresión del derecho que pretendía el demandante-, la demostratio - designación del asunto de la demanda - condemnatio — facultad del juez de condenar o de absolver, y la adiudicatio — adjudicación de algo a algunos de los litigantes por el juez-. La parte extraordinaria se conformaba de la exceptio — posibilidad del demandado de oponerse a la acción del demandante una
} 
privado que había sido designado por las partes de común acuerdo para la solución de la controversia, y se autorizaba por el magistrado el inicio de la fase ante el juez privado - iussum iudicandi- Se ponía, de este modo, fin a esta primera fase y se daba comienzo a la siguiente. De acuerdo con el contenido de la fórmula redactada por las partes, éstas se comprometían a respetar la sentencia que el juez privado dictase ${ }^{40}$ - litis contestatio-.

En la segunda fase - apud iudicem - el magistrado traspasaba al juez privado la fórmula que previamente había aprobado - datio actionem -, indicándole los puntos sobre los que debía versar la prueba: declaraciones de las partes, testigos y documentos, juramentos, inspecciones oculares y reconocimientos de dictámenes emitidos por expertos periciales. En iguales condiciones que en el procedimiento de las acciones de ley: la carga de la prueba que correspondía a las partes —onus probando-, debía recaer sobre los hechos alegados por éstas y desarrollarse conforme al principio dispositivo y de libre valoración, para en función del resultado obtenido, dictar sentencia - iudicatum - Vemos como en esta segunda fase, las fórmulas hacían de guías o instrumentos que el magistrado traspasaba al juez privado para que le sirviesen de orientación a la hora de tomar la decisión final sobre la solución a la controversia que le había sido planteada, reflejaba más tarde en la sentencia ${ }^{41}$ —absolutoria o condenatoria - . La cual era redactada por escrito y posteriormente pronunciada por el mismo juez privado de forma oral en presencia de las partes enfrentadas, ajustándose siempre y en todo momento de forma rigurosa a los términos contenidos en la fórmula -officium iudicis-.

Al igual que en el supuesto del procedimiento de las acciones de ley, cuando el juez privado no lograba formarse una convicción clara sobre el asunto que le había sido planteado, éste podía abstenerse de resolver la cuestión - iurare rem sibi non liquere-. En ese caso, el magistrado disponía de la capacidad para nombrar a un nuevo juez privado - mutatio iudicis - que asumiese el encargo de resolver la controversia interpartes a través de la emisión de una sentencia. La sentencia además de ser inapelable y disponer de efecto de cosa juzgada, servía de título ejecutivo - actio iudicati $^{42}$.

El incumplimiento voluntario de la sentencia por el condenado en ella junto a la falta de autoridad del juez privado - revestido únicamente de potestad para decidir sobre la controversia (potestas iudicandi) — y la prohibición del ejercicio de la justicia primitiva - sobre la persona del condenado-, hacían del ejercicio de la correspondiente acción ejecutiva la única posibilidad de garantizar su cumplimiento, tal y como ocurría en el procedimiento de las legis actiones. En el supuesto del processum per formulam, la ejecución de las pretensiones a favor del demandante contenidas en la sentencia de condena se llevaba a cabo a través del ejercicio de la denominada actio

\footnotetext{
alegación, de hecho o de derecho, que rechaza o paraliza la acción ejercitada por éste mismo-, y la praescriptio - destinada a limitar o a concretar el objeto del litigio-. A pesar de lo expuesto, lo cierto es que la estructura de la fórmula variaba en función de la modalidad, condiciones y características de la fórmula que se pretendía realizar. GARCÍA GARRIDO, M.J., Derecho Privado Romano. CasosAcciones-Instituciones. $20^{\text {a }}$ ed.. Op., Cit., pp. 81-84.

${ }^{40}$ RASCÓN GARCÍA C., Síntesis de Historia e Instrucciones de Derecho Romano. $4^{\mathrm{a}}$ ed. Op., Cit., p. 181.; FERNÁNDEZ DE BUJÁN, A., Jurisdicción y Arbitraje en Derecho Romano. Op., Cit., pp. 108113 , y 138-148.

${ }^{41}$ IGLESIAS REDONDO, J., Derecho Romano. Historia e Instituciones. $18^{\mathrm{a}}$ ed. Op., Cit., p. 135.

${ }^{42}$ ORTEGA CARRILlo De AlBornOZ, A., Derecho Privado Romano. Op., Cit., p. 84.
} 
iudicati —acción por lo juzgado- ${ }^{43}$, sustituta de la manus iniectio. A su vez, el demandado, mediante el ejercicio de la exceptio, podía oponerse a la ejecución de las pretensiones del demandante reconocidas en la sentencia dictada por el iudex, tramitándose, de este modo, un nuevo procedimiento cuya pérdida, nuevamente por el demandado, le obligaba al pago del doble de la pretensión reclamada por el actor principal —in duplum ${ }^{44}$-.

Pese a estar prohibida la ejecución de carácter personal propia de la etapa anterior de las legis actio, la transición entre ésta etapa - la de las acciones de ley- y la nueva - la relativa al procedimiento formulario-, originó que durante aproximadamente un siglo, la ejecución de la actio iudicati pudiese desarrollarse desde una doble dimensión: una primera de carácter personal, en la que el interesado, ante el incumplimiento voluntario de la sentencia por el condenado, disponía de la capacidad para apoderarse de su persona en las mismas condiciones que las referidas previamente para el procedimiento de la legis actio per manus iniectio; y una segunda de carácter patrimonial $^{45}$ que recaía sobre todos los bienes que conformaban el patrimonio del deudor, y que generalmente tenía lugar a través de las denominadas bonorum venditio y distractio bonorum.

\section{A. Bonorum Venditio}

La bonorum venditio permitía garantizar la ejecución de la sentencia mediante la toma de todos los bienes que conformaban el patrimonio del deudor, para con su posterior enajenación en subasta judicial tratar de satisfacer la cantidad debida por el deudor al acreedor. De este modo, la bonorum venditio constituyó la forma de ejecución patrimonial más antigua del mundo ${ }^{46}$. Esta modalidad de ejecución consistente en una enajenación en bloque de todo el patrimonio de una determinada persona, en este caso del deudor, se dividía en tres etapas: la posesión de los bienes, la preparación de la subasta judicial y, finalmente, el desarrollo de la subasta judicial ${ }^{47}$.

En la primera de ellas - la posesión de los bienes-, cuando el iudicatus condenado en juicio - no cumplía voluntariamente con lo dispuesto por el juez privado en la sentencia, el vencedor o algunos de los vencedores - en el supuesto de que los acreedores fuesen varios - por iniciativa propia o a instancias del propio deudor cessio bonorum $^{48}$ _ podían solicitar al magistrado ${ }^{49}$ ser puesto en posesión de los bienes

\footnotetext{
${ }^{43}$ RASCÓN GARCÍA, C., Síntesis de Historia e Instrucciones de Derecho Romano. $4^{\mathrm{a}}$ ed. Op., Cit., p. 190.

${ }^{44}$ GARCÍA GARRIDO, M.J., Casuismo y Jurisprudencia Romana-Responsa-. Acciones y Casos. $4^{\mathrm{a}} \mathrm{ed}$. Ed. Ediciones Académicas, Madrid, 2008, p. 81.

${ }^{45}$ MURGA FERNÁNDEZ, J.P., “Antecedentes históricos de la venta en pública subasta”. Revista Anales de Derecho. Vol. 33, No 1, pp. 1-47. Ed. Universidad de Murcia, Murcia, 2015, p. 15.

${ }^{46}$ CAMACHO EVANGELISTA, F., Derecho Privado Romano. $2^{\mathrm{a}}$ ed. Op., Cit., p. 138.

${ }^{47}$ IGLESIAS REDONDO, J., Derecho Romano. Instituciones de Derecho Privado. Op., Cit., p. 214-215.

48 Se trataba de una figura jurídica introducida con la Lex Iulia del emperador Augusto en el 737. De acuerdo con ella, el deudor podía evitar la ejecución sobre su persona junto con la nota de infamia por el impago de sus deudas, cuando manifestada su insolvencia solicitaba al magistrado el beneficium cessionis ex lege Iulia, conforme al cual, ponía sus bienes a disposición de los acreedores para que éstos pudiesen satisfacer sus créditos con el dinero obtenido a través de la venta de sus bienes en subasta judicial. Pero con la condición de que la insolvencia del deudor no hubiese sido creada de forma dolosa por él mismo. TOMÁS TOMÁS, S., La administración concursal: claves para entender su actual régimen jurídico. Ed. Civitas-Thomson Reuters, Cizur Menor (Navarra), 2014, p. 29.
} 
que conformaban el patrimonio del deudor — missio in possessionem o missio in bona-.

Decretada por el magistrado la missio in possessionem, el acreedor pasaba a entrar en posesión de los bienes del deudor apoyado por el interdicto del magistrado concedido al missus - acreedor - para que no se le pudiese impedir la entrada a los bienes inmuebles del deudor y por una acción factum ejercitable contra quién le impidiese dolosamente tomar posesión de los bienes muebles del deudor o dolosamente hubiese dejado de poseerlos ${ }^{50}$.

Estando ya en posesión de los bienes del deudor, la segunda fase - la preparación de la subasta judicial - daba comienzo con la designación del curator bonorum $^{51}$ por los acreedores, previa autorización del magistrado. El curator bonorum además de encargarse de la conservación y guarda de los bienes del deudor, durante los primeros treinta o quince días de la missio in possessionem — dependiendo de si el deudor estaba vivo o muerto, respectivamente-, daba noticias de ésta mediante la realización de avisos públicos con la intención de que el iudicatus pagase su deuda y permitir que el resto de sus acreedores, también interesados en la ejecución de su patrimonio, pudiesen sumarse a ella — proscripto bonorum ${ }^{52}$ -

Transcurridos estos plazos sin que el deudor hubiese efectuado el pago de su deuda o se hubiese opuesto a la actio iudicati derivaba de la misma, el deudor era declarado fallido - fraudatur - y, como resultado, el magistrado nombraba de entre los distintos acreedores un magister bonorum encargado de dirigir la enajenación en subasta judicial del patrimonio del deudor así como de repartir lo obtenido en la misma entre los diferentes acreedores ${ }^{53}$. A tal fin, de forma previa a su inicio, el magister bonorum hacía un inventario de los bienes que conformaban el patrimonio del deudor y redactaba un pliego de condiciones — Lex Venditionis ${ }^{54}$ — en el que se hacían constar

\footnotetext{
${ }^{49}$ GAYO -4,35- afirmaba que la bonorum venditio fue acuñada por el pretor Rutilio Rufo —año 118 a.C.- - con la intención de que los litigantes victoriosos que no podían llevar a cabo la ejecución sobre la persona del deudor - al estar ésta prohibida —, pudiesen hacerlo sobre su patrimonio. TOMÁS TOMÁS resalta el hecho de que GAYO consideraba al pretor Rutilio Rufo como el introductor de esta modalidad de ejecución patrimonial, pero no su creador. Ibidem, p. 27.

${ }^{50}$ BETANCOURT SERNA, F., "Sobre la pretendida transmisibilidad de los interdictos". Revista Anuario de Historia del Derecho Español. № 53, pp. 46-77. Ed. Ministerio de Justicia y Boletín Oficial del Estado, Madrid 1983, pp. 46-77.

${ }^{51}$ La cura era una institución jurídica destinada a servir de suplemento a la tutela, es decir, proveer la defensa de los bienes e intereses de un individuo que por razones particulares no podía atender por sí mismo a la administración de éstos. De ese modo, el curador asumía casi de forma exclusiva la tarea de administrar un patrimonio, dependiente de la nominación como curador del magistrado. Hallando su origen en la Lex Laetoria de circumscriptione adulescentium del año 191 a.C. GARCÍA GARRIDO, M.J., Derecho privado romano. Caso. Acciones. Instituciones. $17^{\mathrm{a}}$ ed. Ed. Ediciones Académicas, Madrid, 2008, p. 57.

52 PÉREZ ÁLVAREZ, M.P., "Las ventas por subasta en la esfera del Derecho Público". Revista General de Derecho Romano. No 14. Ed. Iustel, Madrid, 2010, p. 4.

53 TALAMANCA, M., La ventita all'icanto nel proceso esecutivo romano. Vol. II. Ed. A. Giuffré, Milano, 1956, p. 239.

${ }^{54}$ La redacción del contenido de la Lex Venditionis debía tener lugar en un plazo de diez días si el deudor vivía, y de cinco días si ya había fallecido. Por su parte, la venta de los bienes del deudor tenía lugar en un plazo de treinta días si éste vivía, y de veinte días si éste ya había fallecido. TOMÁS TOMÁS, S., La administración concursal: claves para entender su actual régimen jurídico. Op., Cit., p. 28.
} 
los créditos que existían contra el deudor, el importe y la prioridad ${ }^{55}$ entre ellos. Una vez aprobados por el magistrado, se procedía a su publicación en lugares públicos a fin que esta situación fuese conocida por todos los posibles interesados ${ }^{56}$.

Por último, una vez realizadas todas estas actuaciones, tenía lugar el desarrollo de la enajenación en subasta judicial de todos los bienes que integraban el patrimonio del deudor, siendo adjudicados al mejor postor - bonorum emptor-. Pese a su denominación, el adquirente del patrimonio del deudor no era exactamente un comprador, pues no se comprometía a pagar una cantidad determinada de dinero por la totalidad de los bienes que conformaban el patrimonio del deudor, sino que, como si de un heredero universal del deudor se tratase, se comprometía a hacerse cargo y, por ende, titular de todo el patrimonio del iudicatus - bienes y créditos en forma de activos y pasivos - y a colocarse en la misma posición en la que éste último se encontraba de forma previa al inicio del desarrollo de la subasta judicial.

Ello significaba que el bonorum emptor tenía derecho a cobrar los créditos de los que el deudor fuese titular, pero también la obligación de pagar las deudas de las que éste último también fuese el titular. Precisamente por ello, la puja de los distintos postores que participaban en el desarrollo de la subasta judicial no consistía en el ofrecimiento de una cantidad de dinero determinada por los bienes del deudor, sino en el compromiso de pagar un determinado porcentaje de sus deudas a cambio de todo su patrimonio. Adjudicándosele finalmente los bienes muebles e inmuebles del deudor al postor que se comprometiese a pagar un porcentaje mayor ${ }^{57}$.

Para que el bonorum emptor pudiese cobrar los créditos del concursado y, para que a su vez, sus acreedores pudiesen dirigirse contra él y reclamarle el cobro de los créditos —o parte de ellos - impagados por el deudor, se procedía a la utilización de las acciones Rutiliana y Serviana. Mientras que la acción Rutiliana era una acción con transposición de sujetos, al utilizarse en el caso de la enajenación en subasta judicial de los bienes de un deudor que aún estuviese vivo. La Serviana, permitía construir una ficción en la que se consideraba al bonorum emptor como heredero del iudicatus, siendo utilizada habitualmente en aquellos casos en los que los bienes muebles e inmuebles que iban a ser enajenados a través del desarrollo de la subasta judicial pertenecían a un deudor ya fallecido ${ }^{58}$.

Enajenado todo el patrimonio del deudor a través del desarrollo de la subasta judicial, el procedimiento de ejecución patrimonial continuaba "activo" para él, pues tras la finalización de la enajenación en subasta judicial de todos sus bienes,

\footnotetext{
${ }^{55}$ En materia de derechos de créditos, regía el principio de la par conditio creditorum. A pesar de ello, existían determinados créditos que por su origen o causa se consideraban privilegiados y por tanto preferentes a los restantes a la hora de realizar el cobro. Entre ellos: los créditos del Fisco y el de las ciudades, los créditos garantizados por un derecho real de hipoteca recayente sobre algún bien del deudor, los créditos originados por multitud de circunstancias como el sepelio, la restitución de la dote o la compra de un navío, y los créditos reconocidos por el deudor en un documento privado. La ruptura del principio de la par conditio creditorum dio lugar al nacimiento de la figura jurídica "tercería de mejor derecho". DE FRANCISCI, P., Síntesis histórica del Derecho Romano. Ed. Revista de Derecho Privado, Madrid, 1954, p. 571.

56 AZARA, A. y EULA, E., Novissimo Digesto Italiano. Tomo VII. Ed. Unione Tipográfico-Editrice Torinese, Ristampa, 1979, p. 719.

${ }^{57}$ USÓN DUCH, L., Las subastas judiciales. Ed. Bosch, Barcelona, 1993, p. 76.

${ }^{58}$ IGLESIAS REDONDO, J., Derecho Romano. Historia e Instituciones. $18^{\mathrm{a}}$ ed. Op., Cit., p. 145.
} 
automáticamente recaía sobre su persona la nota de infamia. Situación agravada aún más ante la posibilidad de que transcurrido el año inmediatamente posterior a la finalización de la enajenación en subasta judicial de todos sus bienes, cualquier acreedor titular de un crédito impagado por él, pudiese dirigirse contra su persona y exigirle el pago del mismo. Idéntica situación al de aquellos acreedores que habiendo participado en el desarrollo de la bonorum venditio de los bienes del deudor, solo hubiesen podido recuperar a través de ella una parte del importe de sus créditos, pudiendo - transcurrido ese primer año- dirigirse nuevamente contra el deudor y exigirle el pago del resto del importe de sus créditos - beneficium competentiae ${ }^{59}$ - Si durante ese primer año posterior a la celebración de la enajenación en subasta judicial, el deudor enajenaba sus bienes con la intención de no pagar y, como resultado, defraudar a los acreedores, el magistrado declaraba la enajenación en subasta judicial por no realizada y concedía a los acreedores afectados un interdictum fraudatorium que, junto a la restitutio in integrum, pretendía recuperar la posesión de aquellos bienes muebles e inmuebles que fraudulentamente habían sido vendidos por el deudor ${ }^{60}$.

\section{B. Distractio Bonorum}

El carácter de la enajenación en subasta judicial a través del desarrollo de la bonorum venditio, marcado por ser excesivamente gravosa para el deudor - la no atención o incumplimiento de cualquiera de sus deudas acarreaba para el deudor el despojo de todo su patrimonio y junto a ello la nota de infamia ${ }^{61}$-, motivó que de forma progresiva se fuese introduciendo un procedimiento alternativo, excepcional y privilegiado al de la bonorum venditio: la distractio bonorum.

Se trataba de una modalidad de ejecución alternativa a la bonorum venditio porque en ella no se nombraba magister bonorum, ni se vendía todo el patrimonio del deudor en bloque, sino que el propio curator bonorum designado por el magistrado, además de encargarse de la custodia y administración de los bienes del deudor — como ya se hacía en el procedimiento de la bonorum venditio - también se encargaba de enajenar de forma progresiva los bienes muebles e inmuebles que componían el patrimonio del deudor dependiendo de los créditos que éste tuviese impagados y hasta garantizar el pago de la totalidad de los mismos. Pasando así, de una ejecución de tipo patrimonial y universal, a una ejecución también de tipo patrimonial, pero ya no universal sino particular ${ }^{62}$.

\footnotetext{
${ }^{59}$ FERNÁNDEZ DE BUJÁN, A., Jurisdicción y Arbitraje en Derecho Romano. Op., Cit., p. 152.

${ }^{60}$ La restitutio in integrum consistía en una resolución del magistrado, por la que se declaraba no conocer los efectos de un hecho o acto jurídico determinado. Tratándose pues de una derogación total de los principios del ius civile que el magistrado solemnemente realizaba inspirado en motivos de equidad. Para su aplicación se exigía la existencia de un acto válido según el ius civiles, un perjuicio derivado de éste considerado contrario a la equidad, la no existencia de otro medio jurídico para reparar el daño sufrido y una causa justa. Entendiendo por iusta causa: la edad, la ausencia justificada, el fraude de acreedores y el miedo, solo o error sufrido por el solicitante. GARCÍA GARRIDO, M.J., Casuismo y Jurisprudencia Romana-Responsa-. Acciones y Casos. $4^{\text {a }}$ ed. Op., Cit., pp. 82-85.

${ }^{61}$ La nota de infamia finalmente desapareció con la Lex Iulia. De acuerdo con ésta, el deudor quedaba liberado de ella cuando de forma voluntaria cediese sus bienes a los acreedores para que éstos pudiesen cobrarse sus deudas, y además pudiese justificar que la causa de su insolvencia no le era imputable a él beneficium competentiae-. IGLESIAS REDONDO, J., Derecho Romano. Historia e Instituciones. $18^{\mathrm{a}}$ ed. Op., Cit., p. 145.

62 ARANGIO RUIZ, V., Instituciones de Derecho Romano. Op., Cit., p. 164. Livio -8, 28, 8- fue el encargado de simplificar la institución de la subasta judicial y trasladar la ejecución sobre la persona del
} 
Como señalábamos antes, la distractio bonorum además de ser un procedimiento alternativo, también era excepcional porque solo era utilizada ante determinados supuestos como la ejecución contra personas pertenecientes a la clase senatorial, contra pupilos y contra otro tipo de personas necesitadas de protección, como por ejemplo incapaces sin tutor o curador y herederos de un deudor concursado. $\mathrm{Y}$ privilegiada, porque no imputaba al deudor - como pena añadida a la pérdida de todos los bienes que conformaban su patrimonio- la nota de infamia ${ }^{63}$.

Pese a que la distractio bonorum surgió como una modalidad de ejecución alternativa, excepcional y privilegiada frente a la bonorum venditio, con el paso del tiempo, fue evolucionando y cambiando hasta llegar finalmente a sustituir plenamente a la bonorum venditio y convertirse así en la principal forma de ejecución ${ }^{64}$. De ese modo, la distractio bonorum se alzó como la primera forma de ejecución singular del Derecho Romano y el primer antecedente de lo que en el Derecho actual conocemos por subasta judicial.

\section{El procedimiento extraordinario o cognitio extra ordinem}

La llegada a Roma de una nueva etapa, el Principado, acompañada de un conjunto de transformaciones de toda índole, incluidas las de tipo jurídico caracterizadas esencialmente por la concentración del poder en torno a la figura del príncipe, considerado fuente creadora del Derecho-, y la sustitución de las antiguas magistraturas por las nuevas - ahora en manos de funcionarios al servicio del Príncipe-, acabó por desencadenar en la progresiva decadencia del processum per formulam. Y es que aunque durante su vigencia ya tuvieron lugar algunos casos en los que el litigio terminó siendo resuelto directamente por el propio magistrado que conocía del asunto en la fase in iure del procedimiento ${ }^{65}$, hubo que esperar hasta el Siglo III d.C. para asistir a su desaparición definitiva - por una Constitución de Constancio y Constante del año 342 - y con él, del Ordo Iudiciorum Privatorum, tras su sustitución por la cognitio extra ordinem, denominada así porque la solución que ponía fin al conflicto interpartes se adoptaba fuera o al margen del Ordo Iudiciorum Privatorum ${ }^{66}$.

El desarrollo de este procedimiento per extraordinaria cognitio procedimiento extraordinario- puso fin a la clásica bipartición del procedimiento de ejecución romano del Ordo Iudiciorum Privatorum en dos fases: una primera, in iure; y una segunda, apud iudicem. Así, la práctica procesal generalizada pasó a ser la de resolver los litigios por medio de una única vía judicial: extra ordinem —ante el

\footnotetext{
deudor — persona corpus obnoxium - al patrimonio de éste — bona debitoris-. D’ORS J.A., Derecho Privado Romano. $10^{\mathrm{a}}$ ed. Op., Cit., p. 172.

${ }^{63}$ FERNÁNDEZ BARREIRO, A. y PARICIO, J., Fundamentos de Derecho Patrimonial Romano. Op., Cit., p. 120.

${ }^{64}$ LUQUE TORRES, G., Las subastas judiciales: aspectos civiles, procesales e hipotecarios. Op., Cit., p. 13; TOMÁS TOMÁS, S., La administración concursal: claves para entender su actual régimen jurídico. Op., Cit., p. 28.

${ }^{65}$ Algunos fragmentos del Digesto señalan que ya en época Republicana determinadas controversias eran resueltas directamente por los magistrados de la fase in iure del procedimiento. A modo de ejemplo podemos señalar: los casos de impago de rentas debido a la ausencia prolongada en el tiempo de los arrendatarios, los fideicomisos, las causas sobre prestación de alimentos, y las causas incoadas por impago de honorarios de profesionales —iudex datus-. CAMACHO EVANGELISTA, F., Derecho Privado Romano. $2^{\mathrm{a}}$ ed. Op., Cit., p. 144.

${ }^{66}$ IGLESIAS SANTOS, J., Derecho Romano. 16a ed. Op., Cit., p. 135.
} 
magistrado-, al constituir ésta, la forma normal de resolver los conflictos ${ }^{67}$. La generalización de la cognitio extra ordinem estuvo ligada al hecho de que las resoluciones dictadas por los nuevos magistrados admitían apelación ${ }^{68}$-ad quem-, posibilidad no ofrecida por los juicios del Ordo Iudiciorum Privatorum, en los que la sentencia del Iudex Privatus creaba una situación jurídica definitiva - efecto de cosa juzgada - resultado del acuerdo previo celebrado entre las partes, conforme al cual, se comprometían a respetar, admitir y someterse a la sentencia dictada por el juez privado. Todo ello materializado a través de la litis contestatio ${ }^{69}$.

La ampliación de las competencias reconocidas al magistrado, conocedor ya no solo de la controversia interpartes, sino también de la prueba de los hechos alegados; la eliminación del convenio arbitral representado a través de la litis contestatio, que originó la desaparición de la fórmula y con ella, la del principio de oralidad - sustituido por el de escritura, necesario para la formulación de la demanda y su contestación, el levantamiento de las actas y la emisión de la sentencia, la cual posteriormente era leída en público por el magistrado-; y la resolución del litigio mediante la emisión de la sentencia, en forma de decreto, directamente por el magistrado — revestida no solo de fuerza declarativa sino también ejecutiva-; se alzaron como los rasgos diferenciadores y significativos del nuevo procedimiento de la cognitio extra ordinem ${ }^{70}$.

$\mathrm{Su}$ inicio tenía lugar a través de la citación de las partes a comparecer en juicio $^{71}$, teniendo ambas la obligación de garantizar su comparecencia ante el magistrado mediante la prestación de la denominada cautio iudicio sisti - caución de comparecer en juicio-. Si alguna de las partes enfrentadas optaba por no comparecer ante el magistrado era declarada contumax, continuando el correcto y normal desarrollo del resto del procedimiento y la emisión de la sentencia final en su ausencia.

Estando ya en presencia del magistrado, las partes y sus abogados prestaban el iusiurandum calumniae - juramento de calumnia por medio del cual juraban no hacer uso fraudulento del Derecho-. A continuación, el actor manifestaba sus pretensiones — narratio - y, seguidamente, el demandado además de hacer lo propio contradictio-, contaba también con la posibilidad de exponer sus argumentos defensivos - praescriptiones o exceptiones - sobre los que se fundamentaba su oposición a la pretensión expresada previamente por el demandante -litis contestatio - . Finalizada las intervenciones de las partes, intervenían sus abogados para la práctica de pruebas testimoniales de honestiores — ciudadanos acomodados-,

\footnotetext{
${ }^{67}$ IGLESIAS REDONDO, J., Derecho Romano. Historia e Instituciones. $18^{\mathrm{a}}$ ed. Op., Cit., p. 149.

${ }^{68}$ El Príncipe, al ser fuente creadora del Derecho, se atribuyó de modo propio la facultad de modificar todas las decisiones que los magistrados previamente habían adoptado extra ordinem, lo que permitía a cualquier persona que hubiese obtenido una sentencia desfavorable poder recurrir ante él. Su uso generalizado, le obligó a delegar esta facultad en sus funcionarios para que fuesen ellos quienes resolviesen en apelación las controversias - magistrados e iudex pedaneus o datus- RASCÓN GARCÍA, C., Sintesis de Historia e Instrucciones de Derecho Romano. $4^{\text {a }}$ ed. Op., Cit., p. 207.

${ }^{69}$ Ibidem, p. 207.

${ }^{70}$ FERNÁNDEZ DE BUJÁN, A., Jurisdicción y Arbitraje en Derecho Romano. Op., Cit., pp. 162-163.

${ }^{71}$ La citación de las partes a comparecer en juicio era denominada litis denuntiatio, cuando tenía lugar por iniciativa privada de alguna de las partes del procedimiento, y evocatio, si se realizaba de forma escrita - litteris - por un organismo oficial. Como resultado de su evolución, su inicio paso a tener lugar a través de un escrito que contenía las pretensiones y los fundamentos jurídicos del actor, entregado posteriormente por éste al Juez, para que a su vez procediese a su notificación oficial al demandado a través de la emisión de un executor. Una vez recibido por el demandado, éste respondía con el libellus contradictionis. CASINO MORA, F.J., Derecho Privado Romano. Op., Cit., p. 279.
} 
documentales — con preferencia de los tabelliones (documentos redactados por funcionarios públicos y notarios)-, periciales y presunciones tanto iuris et de iure, como de iuris tantum. Siempre conforme al régimen de la carga de la prueba -onus probando - , el principio inquisitivo del magistrado en el procedimiento y la valoración tasada de la prueba - y la realización de sus alegatos finales. Por último, el magistrado dictaba por escrito la sentencia y la exponía en audiencia pública — generalmente ante el personal del tribunal y las partes inmersas en el conflicto-, poniendo, de este modo, fin al procedimiento. Salvo que fuese apelada ${ }^{72}$ adquiría de un modo automático efecto de cosa juzgada ${ }^{73}$.

En lo concerniente, en esta etapa, a la ejecución forzosa y de manera ya más concreta a la subasta judicial, debemos comenzar señalando que al igual que ocurría en la etapa inmediatamente anterior -Ordo Iudiciorum Privatorum-, ante el incumplimiento voluntario por el condenado de la sentencia que había sido dictada por el magistrado en el plazo de dos meses, el interesado tenía el derecho y la posibilidad de solicitar su ejecución únicamente a través del ejercicio de la actio iudicati. En este sistema procesal, la ejecución, con carácter general y salvo raras excepciones, era exclusivamente de tipo patrimonial. Pero con múltiples e importantes diferencias en la práctica jurídica, dependiendo de que existiesen uno o varios acreedores ${ }^{74}$.

Cuando el acreedor era solo uno, la ejecución patrimonial sobre sus bienes tenía lugar de manera diferente dependiendo de si la condena recaía sobre la entrega de una determinada cosa o sobre el pago de una suma de dinero concreta:

- Si la condena recaía sobre la entrega de una determinada cosa - certae res - , la ejecución era realizada por funcionarios — apparitores - designados por el magistrado que habían conocido y resuelto la cuestión objeto de controversia - manu militari-. Esos apparitores — funcionarios públicos - eran los encargaban de entregar la cosa objeto de la sentencia al actor. Si no era posible efectuar dicha entrega, procedían entonces a su transformación en dinero y a la posterior entrega de éste al actor, hasta el límite de lo debido por el deudor ${ }^{75}$.

- Si la condena recaía sobre el pago de una concreta suma de dinero certa pecunia - , se procedía a tomar del patrimonio del deudor un número de bienes cuyo valor fuese suficiente para poder hacer frente al pago de la cantidad debida pignus in causa iudicati captum-. Al igual que en el caso anterior, los bienes que

\footnotetext{
${ }^{72}$ La posibilidad de apelar la sentencia que había sido dictada por el magistrado se sustentaba — según ULPIANO- en la intención de corregir la injusticia y la impericia de los magistrados. En el plazo de dos o tres días desde la emisión de la sentencia por el magistrado, el condenado podía interponerla ante ese mismo magistrado verbalmente - pronunciando el vocablo appello —, o por escrito - a través de un libellus appellatorius - . La presentación de la apelación a la sentencia, implicaba la automática suspensión de su ejecución. De modo que, si finalmente era aceptada, el magistrado redactaba una relación de todas las actuaciones desarrolladas - littera dimissoria - que más tarde entregaba a las partes, para éstas a su vez la trasladasen al funcionario superior. Recibida la littera dimissoria por el funcionario superior, se procedía a la repetición del juicio. Si la apelación era iusta y prosperaba, el funcionario podía optar por declarar la nulidad de la sentencia impugnada y dictar otra nueva, o sólo lo primero, en cuyo caso debía iniciarse un nuevo procedimiento. Pero si, por el contrario, era iniusta y no prosperaba, el condenado podía recurrir otra vez, pero con el límite de la tercera instancia, donde la sentencia devenía firme. PANERO GUTIÉRREZ, R., Derecho Romano. $4^{\text {a }}$ ed. Op., Cit., pp. 198-199.

${ }^{73}$ CASINO MORA, F.J., Derecho Privado Romano. Op., Cit., pp. 280-284.

${ }^{74}$ ARANGIO RUIZ, V., Instituciones de Derecho Romano. Op., Cit., p. 173.

${ }^{75}$ ORTEGa CARrillo DE AlbORnOZ, A., Derecho Privado Romano. Op., Cit., p. 93.
} 
conformaban el patrimonio del deudor eran tomados -primero muebles y subsidiariamente inmuebles - por funcionarios previamente designados por él eran liberados y retornados a su patrimonio, pero de no ser así, se procedía a su enajenación en subasta judicial para con las cantidades obtenidas pagar al actor la cantidad debida por el deudor ${ }^{76}$ - magistrado- - Si en el plazo de dos meses, el deudor pagaba su deuda, los bienes

Por otro lado, cuando los acreedores eran varios, la ejecución dirigida contra el patrimonio del deudor, podía ser iniciada bien a instancia del propio deudor a través de la cessio bonorum - antes analizada - o bien a instancia de los propios acreedores por medio de la tradicional bonorum venditio, combinada ahora con la distractio bonorum. En este segundo caso, la ejecución sobre los bienes del patrimonio del deudor se ajustaba a los mismos parámetros que existían en el anterior processum per formulam, pero con determinadas especialidades o novedades:

- El curator bonorum designado por el magistrado, además administrar y custodiar los bienes del deudor, también se encargaba de su venta en subasta judicial. No se nombraba por tanto magister bonorum.

La venta de los bienes del deudor en subasta judicial no tenía lugar en bloque sino particularmente hasta satisfacer la cantidad debida por el deudor.

Se recuperó la imputación de la nota de infamia para el deudor.

\section{LA SUBASTA JUDICIAL EN EL DERECHO HISTÓRICO ESPAÑOL}

La regulación de la subasta judicial en el Derecho romano fue posteriormente recepcionada por el Derecho histórico español visigodo, medieval y contemporáneo a través de diferentes instituciones - el Fuero Juzgo, el Fuero Viejo de Castilla, el Fuero Real, las Leyes de Estilo, las Siete Partidas, el Ordenamiento de Alcalá, las Leyes de Toro, y la Nueva y Novísima Recopilación- que pese al transcurso del tiempo y el cambio de circunstancias, han sido capaces de transformarse y adaptarse a la realidad vigente del momento concreto, hasta llegar a nuestros días.

\section{EI Derecho histórico español anterior a las Siete Partidas}

\section{A. Liber Iudiciorum — libro de los juicios — o Fuero Juzgo}

Tras la caída del Imperio Romano de Occidente - año 476- y la ocupación de la Península Ibérica por los $\operatorname{Godos}^{77}$, dio comienzo una nueva etapa que en el ámbito

\footnotetext{
${ }^{76} \mathrm{Si}$ el rematante - mejor postor - de la subasta judicial no efectuaba el pago del precio comprometido, los apparitores - funcionarios públicos al frente de la ejecución- volvían apoderarse de los bienes subastados judicialmente y continuar de nuevo con la misma subasta judicial previamente ya iniciada. $\mathrm{Si}$ no se presentaban licitadores, o los existentes no aportaban un precio razonable por los bienes subastados judicialmente, el acreedor podía adjudicárselo en compensación de lo que se le debía. DE FRANCISCI, P., Sintesis histórica del Derecho Romano. Op., Cit., p. 573.

${ }^{77}$ A principios del Siglo V, los Godos — un pueblo germánico - traspasaron los ríos Rin y Danubio para asentarse en las extensas provincias del Imperio Romano. Pese a ser vistos como barbari - bárbarospor los romanos, su naturaleza aguerrida y bélica fue la que obligo al propio emperador romano Valente acogerlos como aliados en la lucha con otros pueblos. Tras serle encomendada la misión de expulsar a los bárbaros de Hispania - y ser ésta cumplida - asumieron — una vez caído el Imperio Romano de Occidente (año 476) - el control de las tierras de Hispania. Fundando en ellas un nuevo reino: el Reino de Tolosa. CORONAS GONZÁLEZ, S.M., Manual de Historia del Derecho Español. $2^{\mathrm{a}}$ ed. Ed. Tirant lo Blanch, Valencia, 1999, pp. 87-89.
} 
jurídico se tradujo en la continuación de la anterior etapa romanista. Esta nueva etapa, consolidada durante el reinado de Leovigildo —años 572 -586-, supuso el nacimiento del Reino de Toledo $^{78} \mathrm{y}$, por ende, el asentamiento de las bases de un nuevo Estado que perseguía la unificación política, social, cultural y jurídica de los Godos e Hispano-romanos, hasta su derrumbamiento definitivo con la invasión musulmana tras la batalla de Guadalete en el año 711 .

La unificación jurídica a la que acabamos de hacer referencia se consiguió a través del mantenimiento del principio de personalidad de las leyes. En virtud del cual, los Godos seguían viviendo conforme a su propio Derecho y los Hispano-romanos de acuerdo al Derecho postclásico - Iura e Leges - y al Derecho romano vulgar, siendo todo ello plasmado en el Líber Iudiciorum o Fuero Juzgo ${ }^{79}$. TOMÁS Y VALIENTE puso de manifiesto como este texto jurídico —el Líber Iudiciorum -, promulgado en el año 654 por el rey Recesvinto ${ }^{80}$, tenía como objetivo principal acabar la labor que previamente había sido iniciada por su padre, el rey Chindasvinto. De ese modo, este nuevo cuerpo legal constituyó una recopilación revisora del Código de Leovigildo que reafirmaba el poder legislativo del monarca y su condición como creador del Derecho, al tiempo que se convertía en el único texto jurídico que se podía evocar ante los Tribunales de Justicia ${ }^{81}$.

Hay que señalar que, aunque existían textos jurídicos previos al Líber Iudiciorum - las Leyes Teodorocianas, el Breviario de Alarico II y el Código de Leovigildo, entre otros muchos-, no es hasta la promulgación de éste último cuando obtenemos el primer texto jurídico visigodo en el que se hace referencia o se recoge, de

\footnotetext{
${ }^{78}$ El Reino Visigodo de Tolosa - con capital en la ciudad gala de Tolosa- comenzó en el año 418 tras el pacto entre los visigodos y Roma - antes referido - y duró hasta el año 507, momento en el que el Rey Alarico II fue derrotado por los francos en la batalla de Vouillé. Tras la derrota sufrida a mano de los galos, los visigodos se vieron obligados a retirarse hasta las tierras de Hispania, donde tras vencer a los bárbaros, y como resultado de la mezcla con sus gentes, se inició el periodo ostrogodo (año 507-559) que finalmente permitió constituir el Reino Visigodo de Toledo con capital en Toledo (año 555-711).

${ }^{79}$ PÉREZ BUSTAMANTE, R., Historia del Derecho Español. Las Fuentes del Derecho. Ed. Dykinson, Madrid, 1997, pp. 58-59.

${ }^{80}$ Este Código Legal compuesto por unas 526 leyes - 319 pertenecientes a Leovigildo, 88 a Recesvinto, 98 a Chindasvinto, y otras muchas a los quince capítulos del Libro I de las Etimologías de San Isidrodivididas, como el Código Justiniano, en doce libros - Libro I de la "Ley y el Legislador"; Libro II "de la Organización Judicial y el Procedimiento"; Libros III, IV y V “del Derecho Civil”; Libros VI,VII,VIII, y IX "del Derecho Penal"; y Libros X, XI, XII, y XIII "de materias diversas"-, que a su vez se subdividían en varios títulos, constituyó uno de los documentos más celebres e importantes de la época. "Su aplicación tuvo lugar en calidad de fuero local en los territorios meridionales a Castilla según progresaba la reconquista, manteniéndose vigente hasta la aprobación del Código Civil a finales del siglo XIX'. TOMÁS Y VALIENTE, F., Manual de Historia del Derecho Español. Ed. Tecnos, Madrid, 2010, pp. 162-163.

81 “Líber Iudiciorum, II, 1,8: permitimos y aceptamos que se investigue en las leyes de otros pueblos para aprovechar su utilidad, pero las rechazamos y prohibimos en la tramitación de los pleitos, pues aunque brillen por su lenguaje, sin embargo presentan dificultades. Por lo cual como para lograr la justicia el examen de las razones y el orden debido de las palabras, bastan las leyes que se contienen en este código, no queremos soportar ya más las leyes romanas o de las instituciones extrañas. Y en el mismo sentido Líber Iudiciorum, II, 1,11: Antiqua: que no sea oída por los jueces ninguna causa que no esté regulada en las leyes. Ningún juez pretenda entender en una causa no contenida en las leyes, sino que el conde de la ciudad o el juez, ya por sí mismo o por un ejecutor suyo, hagan presentar a ambas partes ante el Rey, a fin de que el asunto sea concluido más fácilmente y por la potestad real se vea de qué manera la cuestión planteada deba insertarse en las leyes". FERNÁNDEZ ESPINAR, R., Antología de textos jurídicos históricos. Ed. TAT, Granada, 1990, p. 242.
} 
forma expresa, algún aspecto relacionado con la subasta judicial. Concretamente por medio de las Leyes I y III, del Título VI, del Libro V.

La Ley I, del Título VI, del Libro V - De non prendar-, recogía la prohibición de tomar en prenda - ocupar — los bienes del deudor a iniciativa propia del acreedor. Pues al quedar complementada con la Ley XXI del mismo título y libro, se afirmaba que la iniciativa de la "prendación" y enajenación en subasta judicial de los bienes del deudor correspondía al acreedor, pero debiendo éste último actuar siempre y en todo momento bajo la previa autorización del juez. Ya que en caso contrario, la prenda no producía efecto alguno $\mathrm{y}$, como resultado, los bienes prendados eran devueltos a su propietario ${ }^{82}$. De este modo, la obtención de la autorización judicial constituía un requisito esencial y primordial para poder enajenar en subasta judicial los bienes del deudor que previamente le habían sido prendidos.

Por su parte, la Ley III, del Título VI, del Libro V —Del penno que es dado por debda ${ }^{83}$ - regulaba la obligación de que los bienes del deudor que habían sido prendidos se enajenasen mediante la fijación de un precio acordado previa y libremente entre el acreedor y tres hombres buenos, devolviendo al deudor el sobrante que pudiese existir tras la enajenación de sus bienes y la satisfacción de la deuda del acreedor.

Los monarcas Wamba (año 672-680) y Ervigio (año 680-687) llevaron a cabo la primera modificación del contenido del Liber Iudiciorum, pero conservando la estructura y el contenido original de la obra. Más tarde, durante el reinado de los reyes Égica (año 687-702) y Witiza (año 700-711), de nuevo, este mismo texto jurídico experimentó un nuevo cambio respecto a su contenido al incorporar las normas relativas a la cuestión judía. Estas redacciones se conservaron y transmitieron hasta la Edad Media, incorporando simultáneamente nuevos materiales en función del momento concreto - textos jurídicos del Concilio de Toledo y textos doctrinales de San Isidoro-

Ya en Castilla, encontramos las primeras versiones del Liber Iudiciorum traducidas al idioma vulgar — Vulgata - , que junto con las versiones realizadas previamente al romance peninsular - Fuero Juzgo - sirvieron para expandir, temporal y territorialmente, la continuidad del Derecho visigodo hacia nuevos territorios cristianos que habían sido reconquistados al Islam ${ }^{84}$ y establecer el Líber Iudiciorum como punto de partida del Derecho medieval ${ }^{85}$-a él, aludieron posteriormente textos jurídicos medievales como la Lex Gótica o Forum Iudicium-.

\section{B. Fuero Viejo de Castilla}

\footnotetext{
82 "Si alguno omne vende o da cosa ante que la venza por iudizio, o la mandar tomar sin mandato del iuez, el iuez la deve entregar manteniente a aquel que la tomaron...".

83 "El penno que es dado por debda, si ende fue hecho escripto de la debda, hy el debdor prometio en aquel escripto que pagarie la debda al plazo, después del plazo pasado fasta X días, el que lo acrovó, debe guardar los pennos...E si el debdor non viniere e non pagare la debda en aquellos $X$ días assi cuemo es de suso dicho, estonz el acreedor ensenne el penno al sennor, e cuanto asmaren el hy tres omnes buenos, por tanto lo venda: hy el acreedor tome del penno quantol debe dar el sennor por penno, hy lo demas rendalo al sennor del penno", MARTÍNEZ ALCUBILLA, M., Colección de Códigos y Leyes de España. Códigos antiguos. Tomo I. Ed. Roig, Madrid, 1865, pp. 52-54.

${ }^{84}$ CORONAS GONZÁLEZ, S.M., Manual de Historia del Derecho Español. $2^{\mathrm{a}}$ ed. Op., Cit., pp. 95-96.

${ }^{85}$ GACTO FERNÁNDEZ E., ALEJANDRE GARCÍA, J.A., GARCÍA MARÍN, J.M., Manual Básico de Historia del Derecho. Ed. Laxes, S.L. Fotocomposición, Madrid, 1999, p. 188.
} 
Con posterioridad al Liber Iudiciorum, hemos de referirnos, como antecedente histórico en el tema que nos ocupa, al Fuero Viejo de Castilla — promulgado en el año 1248, durante el reinado del rey Alfonso VIII- El aspecto más destacado de este texto legal con relación a la enajenación en subasta judicial de los bienes muebles e inmuebles que comprenden el patrimonio del deudor como instrumento jurídico para la obtención de los recursos económicos necesarios para hacer frente al pago de su deuda fue el establecimiento de un conjunto de normas encargadas de regular sus diferentes aspectos. Normas que quedaron recogidas a través de las Leyes I, II y IV, del Título IV, del Libro III - De las debdas - Estas normas eran las encargadas de regular la obligación del deudor - ante la falta de recursos económicos con los que poder hacer frente al pago de su deuda - de entregar al acreedor los bienes de los que disponía, para con su enajenación en subasta judicial tratar de hacer frente al pago de su deuda.

Si disponía de bienes, el deudor tenía la obligación de entregar al acreedor en primer lugar sus bienes muebles, desarrollándose su enajenación en subasta judicial en el plazo de nueve días a contar desde el momento de la entrega de los mismos. En caso de que los bienes muebles entregados por el deudor, para que a través de su enajenación en subasta judicial poder obtener los recursos económicos con los que hacer frente al pago de la deuda contraída con el acreedor, fuesen insuficientes; el acreedor disponía de la facultad de dirigirse contra los bienes inmuebles del deudor — si había—, pero con diferente régimen en función de la condición de éste, del deudor.

En caso de que el deudor no tuviese atribuida la condición de fijosdalgo noble-, el acreedor en virtud de la Ley IV, del Título IV, del Libro III adquiría la posesión de sus bienes inmuebles para posteriormente enajenarlos en subasta judicial, satisfaciendo así su crédito. El deudor permanecía en prisión hasta la enajenación de los mismos a través del desarrollo de la subasta judicial ${ }^{86}$. Pero si por el contrario, si el deudor tenía atribuida la condición de fijosdalgo ${ }^{87}$ —noble-, el acreedor contaba únicamente con la posibilidad de ocupar sus bienes inmuebles e instituir sobre ellos un régimen de administración forzosa, durante el tiempo que fuese necesario, para tratar de ese modo satisfacer su crédito - Ley I, del Título IV, del Libro III-. Situación resultante de la prohibición establecida por el Fuero Viejo de Castilla - Ley II, del Título IV, del Libro III- de enajenar en subasta judicial los bienes inmuebles del deudor cuando éste último dispusiese de la condición de fijosdalgo y, obviamente, la

\footnotetext{
86 "E la vendida que ansi fuer fecha debe vale a aquel que la compro por fuero, e non salga él ante de la prision fasta que otorgue la vendida". Siendo reiterada posteriormente esta misma idea en la Ley XIII, del Título IV, del Libro III — encargada de regular la realización de los bienes de carácter semimovientes (animales o ganado)—. TOMÉ PAULÉ, J., "La subasta judicial en el derecho histórico español". Op., Cit., p. 1042.

87 El Fuero Viejo de Castilla se componía de doscientas treinta y dos leyes, treinta y tres títulos, doscientos cuarenta capítulos, y cinco libros -Libro I "Derecho Público"; Libro II "Derecho Penal"; Libro III "Organización judicial y procedimientos"; Libros IV y V "Derecho Civil"- entre los que se contienen diversas prescripciones de Derecho Nobiliario. De ahí que está obra también fuese conocida como Fuero de los Fijosdalgo -ESCUDERO, J.A., Curso de Historia del Derecho. Fuentes e Instituciones Político-Administrativas. Ed. Solana e Hijos, A.G., S.A.U., Madrid, 2012, p. 438-. Sin embargo, a pesar de ello, no puede ser considerada un código nobiliario, pues según GALO SÁNCHEZ también contiene otros muchos preceptos que nada tienen que ver con tales cuestiones - SÁNCHEZ, G., "Para la historia de la redacción del antiguo derecho territorial castellano". Anuario de Historia del Derecho Español. N ${ }^{\circ}$ 6, pp. 260-328 Ed. Ministerio de Justicia y Boletín Oficial del Estado, Madrid, 1929 , p. 260 -.
} 
interdicción de la pena de prisión por deudas cuando el deudor tuviese atribuida la condición de fijosdalgo — Ley X, del Título IV, del Libro III-.

Conforme a la Ley IV, del Título IV, del Libro III — ya antes mencionada—, la autorización de la prenda de los bienes inmuebles del deudor y la tramitación de su enajenación en subasta judicial eran tareas que correspondían al Alcalde — juzgador de la época-, quién a su vez encomendaba al corredor la realización de las gestiones necesarias para, de forma real y efectiva, poder llevarla a cabo. Así, el corredor ofrecía los distintos bienes del deudor a terceras personas interesadas en su adquisición, tomando nota de las diferentes ofertas realizadas por cada uno de ellos para posteriormente comunicárselas al Alcalde, quién procedía a enajenar el bien a la persona que hubiese ofrecido el mejor precio por ellos. Efectuada la enajenación y transmisión de los bienes del deudor, se le obligaba a efectuar a éste último el otorgamiento de escritura de enajenación a favor de la persona que adquiría el bien inmueble. Si una vez satisfecho el crédito del acreedor con la enajenación en subasta judicial de los bienes del deudor existía sobrante, éste era entregado al deudor ${ }^{88}$.

\section{Fuero Real o Fuero del Libro}

La difusión del Fuero Juzgo por las tierras cristianas recién conquistada al Islam no presentó grandes obstáculos, pues este Derecho conectaba en gran medida con el que sus gentes habían experimentado hasta entonces aunque con limitaciones y dificultades ocasionadas por la minoritaria población mozárabe que aún existía en aquellos territorios. Otra cosa muy distinta sucedió en las zonas castellanas donde la presencia de ordenamientos locales formados con anterioridad a la promulgación del Fuero Juzgo seguían constituyendo un importante factor de resistencia contra el viejo Derecho regio de origen visigodo. Esta situación provocó que al comienzo del reinado del rey Alfonso X, los sistemas jurídicos de Castilla y de León estuviesen caracterizados por la diversidad y el localismo. Frente a lo cual, con la intención de poder eludir esta dificultad, el Rey decidió poner en marcha una tarea reformadora y unificadora por la vía local y general, dando como resultado a los dos grandes textos jurídicos de la época: el Fuero Real y las Siete Partidas ${ }^{89}$.

El Fuero Real — promulgado en Valladolid en el año $1255^{90}$ — pretendía acabar con la carencia de fueros y textos jurídicos escritos que permitían el desarrollo

\footnotetext{
88 "E aquel que quesier la prenda métala en manos de su vecino, a este faste otros diez días, cumplido veinte días métala del corredor a vender, e deve tomas señas de aquellos que mas dieron por ello". TOMÉ PAULÉ, J., "La subasta judicial en el derecho histórico español”. Op., Cit., p. 1042.

${ }^{89}$ GACTO FERNÁNDEZ E., ALEJANDRE GARCÍA, J.A., GARCÍA MARÍN, J.M., Manual Básico de Historia del Derecho. Op., Cit., pp. 188-198.

${ }^{90}$ En torno a la fecha exacta en la que se promulgó el Fuero Real, encontramos un pequeño debate doctrinal. Mientras CORONAS GONZÁLEZ defiende que la promulgación del Fuero Real tuvo lugar en Valladolid durante los meses de julio y agosto del año 1255, ESCUDERO, por su parte, mantiene que la promulgación del Fuero Real, efectivamente, se realizó en 1255, y en la ciudad de Valladolid, pero no durante los meses de julio y agosto, como defiende CORONAS, sino de marzo y abril. La solución a este debate doctrinal la encontramos por medio de la intervención de MARTÍNEZ DÍEZ, quién señala que durante los meses de marzo y abril del año 1255, las villas de Aguilar del Campo y Sahagún recibieron un texto jurídico con el nombre de Fuero del Libro - tradicionalmente identificado como Fuero Real一, que una década posterior, en 1265, también fue otorgado a diferentes localidades, entre ellas Valladolid. Aunque esta equiparación presente problemas de ajuste cronológico, tal incongruencia se consigue superar adelantando la datación del texto. Defendiendo así, pues, que la redacción original del Fuero Real tuvo lugar en 1249 bajo el reinado de Fernando III, y que posteriormente fue utilizado en 1255 por el rey
} 
del juicio de albedrío y otros "usos desaguisados de los que nascien muchos males e muchos daños a los pueblos y a los homes", al tiempo que el reforzamiento del poder real a través de la designación del Alcalde y del Juez como los ejes de la nueva política municipal, a fin de establecer una justicia real y pública.

Para ello, este nuevo código jurídico influenciado por el Líber Iudiciorum, el Espéculo - promulgado entre 1255 y 1260. Durante los primeros años del Rey Alfonso X "El Sabio" - y el Derecho romano, se encontraba dividido en cuatro libros ${ }^{91}$ que además de mantener algunas de las ideas ya mencionadas anteriormente y plasmadas en los distintos textos legales señalados hasta el momento ${ }^{92}$, también recogía, a través de los Títulos XIX - De los empeños y prendas - y XX —De las deudas y de las pagasdel Libro III, importantes novedades de algunas de las cuestiones relativas a la enajenación en subasta judicial.

Conforme al contenido de la Ley I y II, del Título XX, del Libro III se establecía que el que debiese a otro y no pagase en tiempo, estaba obligado por mandato del Alcalde a entregar sus bienes - muebles o inmuebles - a su acreedor para que con el resultado de la enajenación de éstos — bienes muebles e inmuebles del deudor- en subasta judicial se pudiese satisfacer el derecho de crédito del acreedor. El procedimiento a seguir para la enajenación de esos bienes en subasta judicial, variaba en función de la naturaleza - mueble o inmueble - del bien objeto de la misma. Así, mientras que en el caso de los bienes muebles el procedimiento de enajenación en subasta judicial tenía una duración de nueve días - a contar desde el momento de la entrega del bien - y estaba dirigido por el corredor bajo mandato del Alcalde; en el caso de los bienes inmuebles, la duración de ese mismo procedimiento de enajenación de los bienes del deudor en subasta judicial se ampliaba hasta los treinta días, se anunciaba en los distintos mercados y se encontraba dirigido por el merino — Juez inferior-, también designado por mandato del Alcalde. Tanto el corredor situado al frente de la subasta judicial de bienes muebles como el merino a cargo de la subasta judicial de bienes inmuebles eran designados por el Alcalde ${ }^{93}$, quedando, de ese modo, su actuación a merced de las órdenes de éste último. El importe obtenido a través de la enajenación en subasta judicial de los bienes del deudor era destinado al pago de la deuda contraída con el acreedor, mientras que el posible sobrante era devuelto al deudor.

Alfonso X. CORONAS GONZÁLEZ, S.M., Manual de Historia del Derecho Español. $2^{\mathrm{a}}$ ed. Op., Cit., p. 264; ESCUDERO, J.A., Curso de Historia del Derecho. Fuentes e Instituciones Político-Administrativas. Op., Cit., p. 446; MARTÍNEZ DÍEZ, G., "El Fuero Real y el Fuero de Soria". Anuario de Historia del Derecho Español. No 39, pp. 545-562 Ed. Ministerio de Justicia y Boletín Oficial del Estado, Madrid, 1969, p. 545.

${ }^{91}$ Libro I "Religión y politica, Derecho público, y Administración de Justicia"; II "Procedimiento y organización judicial"; Libro III "Derecho civil, familia y contratos"; Libro III "Derecho penal, territorial y maritimo". ESCUDERO, J.A., Curso de Historia del Derecho. Fuentes e Instituciones Politico-Administrativas. Op., Cit., p. 446; PÉREZ BUSTAMANTE, R., Historia del Derecho Español. Las Fuentes del Derecho. Op., Cit., p. 63.

92 Prohibición de tomar en prenda los bienes del deudor de forma privada y sin la correspondiente autorización emitida de forma previa por el Juez o por el Alcalde, sancionando a quién lo hiciese con la obligación de devolver la "prenda doblada" al propietario del bien — Ley II, del Título XX, del Libro III-, o la venta del bien subastado a favor del interesado que ofreciese la mayor cantidad de dinero por él, entre otras muchas.

${ }^{93}$ USÓN DUCH, L., Las subastas judiciales. Ed. Bosch, Barcelona, 1993, p. 83. 
La novedad de este texto legal en lo relativo a la enajenación en subasta judicial radicó en el hecho de que frente a lo dispuesto en el Fuero Viejo de Castilla con relación a esta misma cuestión, aquí desaparece la preferencia de los bienes muebles respecto de los bienes inmuebles a la hora tratar de satisfacer la cantidad debida por el deudor a través de su enajenación por medio del desarrollo de la subasta judicial. Pues una vez obtenida la orden del Alcalde, el deudor debe entregar discrecionalmente los bienes muebles e inmuebles que sean necesarios y suficientes para hacer frente al pago de su deuda ${ }^{94}$.

Por otro lado, la Ley IV del mismo título y libro que estamos comentando, prohibía tomar en prenda y posteriormente enajenar en subasta judicial determinados bienes muebles e inmuebles del deudor: bueyes, vacas $\mathrm{u}$ otros animales que fuesen utilizados para trabajar la tierra, así como el pan.

Por último en cuanto al Fuero Real, como bien señala TOMÉ PAULÉ ${ }^{95}$, bajo el término "fagale", encontramos la primera referencia clara relativa al fenómeno de la publicidad de la enajenación de bienes en subasta judicial. Afirmando que esta tenía lugar a través del pregón ordenado por el Alcalde cuando los objetos que se iban enajenar por medio del desarrollo de la subasta judicial eran bienes raíces - "fagale el Alcalde pregonar cada mercado"-

\section{Leyes de Estilo}

Las Leyes de Estilo o también llamadas Declaraciones de las Leyes del Fuero Real - mandadas a hacer por orden del rey Alfonso X durante la segunda mitad del siglo XIII, pero formuladas finalmente a finales del siglo XIII o principios del XIV bajo el mandato del rey Fernando IV (años 1295-1312) - constituyen un Código de doscientas cincuenta y dos leyes relativas a los usos y observancias judiciales estilos - seguidos y practicados en la Corte o Tribunal Regio, así como jurisprudencia de la época, reglas de Derecho y elementos elaborados por la literatura jurídica que pretendían la aclaración de las leyes contenidas en el Fuero Real y la ordenación de las reglas para la correcta Administración de Justicia, a fin de poder conseguir la tan ansiada unificación del sistema legal español vigente en ese momento ${ }^{96}$.

De entre esas doscientas cincuenta y dos leyes relativas a los usos y observancias judiciales seguidos y practicados en la Corte o Tribunal Regio, se encontraron algunas leyes encargadas de establecer las exigencias que eran necesarias cumplir para poder enajenar los bienes del deudor a través del procedimiento de la subasta judicial:

El Rey era el encargado de ordenar que se tomasen y enajenasen en subasta judicial los bienes de aquella persona que era deudora de otra. Pero estableciendo como exigencia, para que la enajenación de los bienes del deudor en

\footnotetext{
${ }^{94}$ Autoriza al "home que tuviere peños por alguna cosa", transcurrido el plazo señalado, a venderlos "con testigos de tres homes buenos, con mandado del alcalde cocejeramente, a quien más diere por ellos, e de lo que debiere haber de mision, o de pena alguna, si la pusiere con el..., e lo demás delo a su dueño...”. LUQUE TORRES, G., Las subastas judiciales. Aspectos civiles, procesales e hipotecarios. Op., Cit., pp. 27-28.

${ }^{95}$ TOMÉ PAULÉ, J., "La subasta judicial en el derecho histórico español”. Op., Cit., p. 1048.

${ }^{96}$ ESCUDERO, J.A., Curso de Historia del Derecho. Fuentes e Instituciones Politico-Administrativas. Op., Cit., p. 449.
} 
subasta judicial fuese válida y desplegase todos sus efectos, la necesidad de dotarla de cierta publicidad durante el tiempo exigido por la Ley - "debelos tomar, et vender pregonándolos primeramente a los plazos quel fuero manda"- - De lo contrario, una vez finalizada, la subasta judicial practicada era automáticamente declaraba nula, con las oportunas consecuencias asociadas a este hecho: la devolución del bien enajenado y el precio por el que finalmente se consiguió enajenar, quedando asistido su comprador - en el desarrollo de la subasta judicial - para el ejercicio, si así lo estima oportuno, de la acción a través de la cual poder dirigirse contra el vendedor - de la subasta judicial, es decir, el deudor - y reclamarle la cantidad por la que consiguió adjudicarse el bien objeto de la subasta judicial durante el desarrollo de ésta - "Et si no lo fizo, et los vendió, o paso a mas de quando le fue mandado, debe ser emplazado el vendedor ante el Rey; et si asi fuere fallado, deben dar la vendida por ninguna, et debenle mandar tornar sus bienes a este cuyos eran" (Ley 219) — ${ }^{97}$.

El precio por el que se enajenaba el bien en la subasta judicial, era el precio que resultaba de la oferta más alta que habían realizado por él, de modo que a la hora de adquirir el bien, no se podía fijar o establecer un precio mínimo. Cuando el bien era enajenado por un precio muy inferior al de su valor real, el deudor-propietario no podía oponerse a este hecho alegando la existencia de una lesión derivada de la enajenación en subasta judicial del bien por un precio inferior al de su valor real — "Que la ley engaño en meytad del justo precio, non ha lugar en las cosas vendidas en almoneda; nin la ley del tanto por tanto" (Ley 220)-.

\section{Las Siete Partidas}

Sin lugar a dudas, un punto de inflexión en el tema que nos ocupa, es la exhaustiva y completa regulación de la institución de la subasta judicial prevista en las Siete Partidas del rey Alfonso X - promulgadas entre los meses de junio y agosto de $1265^{98}{ }_{-9}$.

\footnotetext{
${ }^{97}$ LUQUE TORRES, G., Las subastas judiciales. Aspectos civiles, procesales e hipotecarios. Op., Cit., p. 29.

${ }^{98}$ LÓPEZ, G., Las Siete Partidas. Partidas I y II, Partidas III y IV, y Partidas V, VI y VII. Impreso por Andrea de Portonaris, Salamanca, 1555, pp. 93-94, 85, 102 y 25, 17, 84 y 95-97, y 108.; GÁMEZ MONTALVO, M‥F., GARRIDO ARREDONDO, J., LÓPEZ NEVOT, J.A. y SAINZ GUERRA, J., Textos para una Historia del Derecho Español. Ed. Comares, Granada, 1994, pp. 107-117.

${ }^{99}$ Las Siete Partidas o Septenario - también llamado así por estar su contenido dividido en siete libros-, de acuerdo con su prólogo, tenía como misión principal la de mejorar el cumplimiento de la Justicia y del Derecho en beneficio de sus reinos, y posibilitar a las gentes comunes - a los súbditos de la corona - el conocimiento del Derecho y de la Razón en beneficio de la propia Justicia y del respeto a la autoridad real -PÉREZ BUSTAMANTE, R., Historia del Derecho Español. Las Fuentes del Derecho. Op., Cit., p. 138- Contaba para ello con dos mil quinientas leyes que agrupadas en ciento ochenta y dos títulos conformaban los siete libros en los que quedaba dividido su contenido: Libro I "De las fuentes del Derecho y del Derecho eclesiástico": Libro II "Del Derecho público"; Libro III "De la Organización y el procedimiento judicial"; Libros IV y V "Derecho privado: civil y mercantil"; Libro VI "Derecho Penal"; y Libro VII "Estatuto jurídico de musulmanes y judíos" - CORONAS GONZÁLEZ, S.M., Manual de Historia del Derecho Español. $2^{a}$ ed. Op., Cit., p. 267-. Según ESCUDERO, "la división del contenido de las Partidas en siete libros obedecía a las excelencias que tradicionalmente habian sido atribuidas al número siete por antiguas tradiciones paganas y cristianas, los siete dones del Espíritu Santo de los que hablaban Isaias, San Ambrosio, y el propio San Raimundo de Peñafort a comienzos del siglo XIII" ESCUDERO, J.A., Curso de Historia del Derecho. Fuentes e Instituciones Politico-Administrativas. Op., Cit., p. 450-.
} 
Las Leyes XXXI, XXXII, XXXIII y XXXIV, del Título XXVI, de la Segunda Partida eran las encargadas de regular las distintas circunstancias referentes al desarrollo de la enajenación en subasta judicial. La Ley XXXI fijaba el lugar de celebración de la subasta judicial - habitualmente aquel donde se encontraba el objeto a subastar judicialmente con la intención de que los diferentes postores interesados en su adquisición pudiesen verlo y, como resultado, decidir si participar o no en el desarrollo de la subasta judicial con la intención de adquirirlo- y su finalidad: tratar de conseguir que los bienes que iban a ser enajenados a través del desarrollo de la subasta judicial fuesen apreciados por su valor, evitando engaños y asegurando el cumplimiento de la obligación de pago por el nuevo adquirente - propietario- del bien subastado judicialmente en el plazo establecido para ello — de tres días a contar desde su adquisición- La Ley XXXII, XXXIII, y XXXIV determinaban que personas quedaban autorizadas para poder intervenir en el desarrollo de la subasta judicial, destacando de forma especial la figura del corredor y la de los escribanos. Mientras que el corredor se encargaba de obtener el mejor precio posible por los bienes objeto de la subasta judicial a través del grito público y la anotación de las cantidades que se iban ofertando por ellos; los escribanos procedían a anotar todos y cada uno de los diferentes elementos entre los que tenía lugar el desarrollo de la subasta judicial ${ }^{100}$.

Las Siete Partidas además de establecer el orden de prelación de los bienes sobre los que se debía hacer cumplir la sentencia una vez probada la cantidad debida por el deudor ${ }^{101}$ — Ley III, del Título XXVII, de la Tercera Partida—, también fijó el procedimiento conforme al cual debía transcurrir la subasta judicial para su correcto desarrollo $^{102}$ — Ley VI, del Título XXVII, de la Tercera Partida—. Todo ello debiendo tener presente las siguientes cuestiones:

${ }^{100}$ VELASCO PÉREZ, I., Las siete partidas del sabio rey Don Alonso. Ed. Maxtor, Madrid, 1843, p. 309.

${ }^{101} \mathrm{El}$ orden de prelación de los bienes sobre los que se debía hacer cumplir la sentencia era el siguiente: en primer lugar, se procedía judicialmente contra los bienes muebles que pudiese tener el deudor ejecutado. En caso de que el deudor ejecutado no tuviese bienes muebles en su haber, o teniéndolos, su valor fuese insuficiente para el pago de la deuda, la ejecución se redirigía contra los bienes inmuebles que éste último pudiese poseer. Si el deudor ejecutado no tenía bienes muebles o inmuebles en su haber, o cuando teniéndolos, éstos no tenían el valor suficiente para hacer frente al pago de la cantidad adeudada, se cedía al acreedor aquellos créditos de los que el deudor ejecutado fuese su titular frente a terceros para con su realización sobre los mismos pueda cumplirse la sentencia en su totalidad. Una opción/alternativa a la situación descrita, era la de proceder a la ejecución de caballos y bueyes. Pese al privilegio que recaía sobre estos bienes a la hora de proceder a la realización de bienes del deudor resultado de la existencia de deudas, en defecto de bienes mueves e inmuebles se puede proceder contra ellos cuando en el supuesto de que lo debido no sea una cantidad, sino un bien concreto y determinado, la sentencia se cumple sobre el bien. LUQUE TORRES, G., Las subastas judiciales. Aspectos civiles, procesales e hipotecarios, Op., Cit., p. 31.

102 "Dictada la sentencia si el deudor no pagaba, se toman sus bienes según el orden de prelación antes fijado en la Ley. Esta subasta tenía lugar una vez transcurridos 20 días desde el momento en que tenía lugar la prenda de los bienes, a fin de que todos los interesados estuvieran informados, pudiesen examinar los bienes que se iban a subastar y pudiesen presentar sus posturas. Transcurrido el plazo y presentadas las distintas posturas, se procedia a efectuar la venta en favor de quien hubiere presentado postura más alta. Con el precio se procede al pago de la deuda y si una vez saldada esta queda remanente se entregará al deudor. En el caso de que con el importe obtenido no hubiese suficiente para pagar la totalidad de la deuda, el acreedor tiene derecho a proseguir la ejecución sobre el resto de sus bienes. Si por cualquier causa no tiene lugar el pago del precio en el plazo establecido, 20 días, o no se presentan postores se procede a la adjudicación el bien al acreedor en pago de su crédito. Este derecho de adjudicación del acreedor no se recoge como un derecho que el acreedor tenga en todo momento y todos los casos sino únicamente en este caso que acabamos de describir, cuando no se presenten licitadores y la subasta quede desierta". MORAL MORO, M.J., La subasta judicial de bienes inmuebles, Op., Cit., p. 60. 
- De forma previa al inicio de la enajenación a través de subasta judicial, se exigía que el bien objeto de la misma fuese presentado para su cotejo y examen por los posibles interesados en su adquisición - Ley XVI, del Título II, de la Tercera Partida-

- Exoneración de todo tipo de responsabilidad en aquellos supuestos en los que el bien objeto de la subasta judicial se perdiese sin culpa imputable a ninguna persona, caso fortuito o caso de fuerza mayor. No era así, en los supuestos en los que el deudor culposa o dolosamente hubiese deteriorado el bien prendado - Leyes XVIII y XIX, del Título II, de la Tercera Partida, respectivamente-.

- $\quad$ La ejecución de la sentencia correspondía al Juez que conoció del pleito. Si el bien objeto de subasta judicial se encontraba en un lugar distinto al de celebración del pleito, el Juez del lugar donde se encontrase el bien prendado asumía la obligación de ejecutar la sentencia previamente dictada por el Juez que inicialmente conoció del pleito por medio de la entrega del bien al rematante — Ley I, del Título XXVII, de la Tercera Partida-.

- $\quad$ Cuando la subasta judicial quedase desierta, el acreedor podía solicitar la adjudicación del bien objeto de la misma en pago de su deuda — Ley IV, del Título XXVII, de la Tercera Partida-.

Por otro lado, se recogía la prohibición de enajenar bienes de naturaleza mueble e inmueble cuando éstos perteneciesen a huérfanos, salvo en casos justificados o de gran menester - existencia de deudas o casamiento de una hermana-, pero siendo necesario en todo caso estar en posesión del correspondiente y previo otorgamiento judicial — Ley IV, del Título V, de la Quinta Partida - En esos casos, la enajenación en subasta judicial de los bienes propiedad de los huérfanos se desarrollaba conforme el procedimiento fijado por la Ley LX, del Título XVIII, de la Tercera Partida. De acuerdo con éste, una vez concedido por el juez el otorgamiento judicial necesario para poder iniciar el desarrollo de la enajenación en subasta judicial de los bienes propiedad de los huérfanos, el acto de la subasta judicial se desarrollaba durante un periodo de 30 días, transcurridos los cuales los bienes del deudor objeto de la misma eran entregados a la persona que más hubiese ofrecido por ellos ${ }^{103}$.

La Quinta Partida, a través de su Título XIII "De los peños que toman los omes muchas vegadas por ser mas seguros que les sea mas guardado, o pagado, lo que les prometen de fazer o de dar", regulaba otros aspectos relativos a la forma y a los plazos de la enajenación en subasta judicial:

\footnotetext{
103 "E un estonce de ese facer con otorgamiento del juez del lugar, andando la cosa públicamente en almoneda treinta días". GARCÍA GOYENA, F. y AGUIRRE, J., Febrero Reformado. Tomo I. $4^{\mathrm{a}}$ ed. Imprenta y Librería de Gaspar Roig Editores. Madrid, 1852, pp. 149-150. Los diferentes aspectos relacionados con la administración y demás obligaciones atribuidas a los tutores y curadores de esos mismos huérfanos, quedaban reguladas a través de la Ley 60, del Título XVIII, de la Tercera Partida; la Ley 14, del Título XI, de la Cuarta Partida; la Ley 4, del Título V, de la Quinta Partida; la Ley 8 del Título XIII de la Quinta Partida; y la Ley 18 del Título XVI de la Sexta Partida.
} 
- $\quad$ La forma y el tiempo en que podía enajenarse la cosa empeñada - Ley XLI, del Título XIII, de la Quinta Partida ${ }^{104}$ -

- La enajenación en subasta judicial de los bienes dados en prenda cuando no se hubiese fijado plazo alguno para su desempeño ni tampoco se hubiese acordado cosa alguna en lo relativo a su enajenación - Ley XLII, del Título XIII, de la Quinta Partida ${ }^{105}$.

La enajenación en subasta judicial en aquellos supuestos en el que habiendo intentado el acreedor enajenar en subasta judicial el bien dado en prenda por el deudor, no lo hubiese logrado - Leyes XLIII y XLIV, del Título III, de la Quinta Partida— ${ }^{106}$.

\section{El Ordenamiento de Alcalá y las Leyes de Toro}

Con posterioridad a las Siete Partidas, existieron dos textos legales de gran importancia para el análisis del tratamiento de la subasta judicial en el Derecho histórico español: el Ordenamiento de Alcalá — promulgado por el rey Alfonso XI en 1348 - y las Leyes de Toro - impulsadas a través del codicilo testamental de la reina Isabel I de Castilla antes de su muerte, finalmente, promulgadas por las Cortes de Toro en 1505-. Ambas normas incorporaron importantes avances jurídicos en materia de Derecho civil $\mathrm{y}$ procesal $\mathrm{y}$, por ende, en lo relativo a la institución de la subasta judicial. Constituyendo de ese modo, el núcleo esencial del Derecho privado castellano.

La principal aportación del Ordenamiento de Alcalá - compuesto por ciento veinticinco leyes que se agrupaban en treinta y dos títulos- fue el establecimiento del orden de prelación de las fuentes jurídicas del Derecho castellano ${ }^{107}$. De modo que su

104 "Si transcurrido el plazo concedido para el pago de la deuda éste no tenía lugar, el que recibió la prenda estaba legitimado para venderla en subasta judicial conforme a los siguientes requisitos: 1. La intención del acreedor de vender en subasta judicial la cosa dada en prenda debía de ser comunicada al deudor. 2. Cumplido este requisito comunicativo o no habiéndolo efectuado por casusa no imputables al acreedor, éste último podía ya proceder a la venta del bien en subasta judicial. Si el precio obtenido con la venta en subasta judicial era superior a la cantidad adeudada, el exceso se devolvía al deudor, pero en caso contrario, el deudor quedaba obligado a pagar al acreedor la parte restante hasta cumplir con la totalidad del pago". GUITÉRREZ FERNÁNDEZ, B., Estudios de Derecho Civil. Tomo V. $1^{\mathrm{a}}$ ed. Editorial Lex Nova, Madrid, 1869, p. 312.

${ }^{105}$ La Ley XLII regulaba la venta en subasta judicial de los bienes dados en prenda cuando no se había fijado plazo para desempeñarlos, ni se había hablado cosa alguna sobre su venta. "En este caso el acreedor si quería vender la cosa dada en prenda estaba obligado a: 1. Requerir, en presencia de omes buenos, al que empeñó la cosa para que la dejase sin efecto. Contando con un plazo de 12 días si era mueble, y de 30 días si era inmueble, a contar desde el requerimiento. 2. Si el requerimiento no era atendido, el acreedor podía proceder a la venta en subasta judicial del bien prendado una vez finalizados los cómputos de tiempo antes señalados. 3. Si las partes hubiesen pactado la imposibilidad de vender el bien prendado, para su venta en subasta judicial era necesario que el acreedor requiriese a la persona que lo empeñó por tres veces y ante tres hombres buenos. Si transcurridos dos años, el bien continúa sin ser desprendado, el acreedor está legitimado para venderlo en almoneda". Ibidem, p. 313.

106 En este supuesto y salvo autorización expresa del propietario del bien — deudor-, el acreedor quedaba obligado a solicitar al Juez que se le adjudicase el bien en pago de su deuda. De forma que, si finalmente el bien del deudor valía más que el importe del crédito del acreedor insatisfecho por el deudor, el acreedor devolvería el exceso a su dueño, al deudor. De forma contraria, el acreedor tendría el derecho a ejercitar contra el deudor la correspondiente acción con la intención de demandarle y exigirle el pago de la parte que faltase por cubrir. LUQUE TORRES, G., Las subastas judiciales. Aspectos civiles, procesales e hipotecarios, Op., Cit., p. 33-34.

${ }^{107}$ El orden de prelación de las fuentes jurídicas del Derecho castellano establecido a través de la Ley I, del Título XVIII del Ordenamiento de Alcalá disponía que en primer lugar debía aplicarse el Ordenamiento de Alcalá; en segundo lugar y en su defecto los fueros municipales pero con una serie de 
vinculación con la institución procesal de la subasta judicial se fundamentaba en que la única ley de su Título XVIII determinaba que en caso de enajenación de un bien en subasta judicial, si el comprador o el vendedor eran engañados en más de la mitad del precio de lo que realmente el bien subastado judicialmente valía según Derecho, las partes quedaban obligadas a cumplir de acuerdo con el precio que correspondiese, atendiendo a su valor real, y a devolver el vendedor al comprador lo que cobró de más en el precio, y a la inversa, lo que el comprador pagó de menos al vendedor a la hora de adquirir los bienes. Como vemos, la novedad que se recoge en el contenido de esta Ley gira en torno al distanciamiento con respecto del criterio seguido por la anterior Ley 220 de las Leyes de Estilo: "el precio de venta de los bienes objeto de subasta judicial era el que resultaba de la subasta judicial, sin posibilidad de reclamación, devolución, exceso o defecto de su precio"108.

Esta norma correctora del precio de enajenación del bien subastado judicialmente era exigible a todos los sujetos que participaban en ella, extendiéndose su vigencia durante un plazo de cuatro años — plazo de prescripción para la reclamación del exceso- a contar desde el día en que tuvo lugar su enajenación en subasta judicial $^{109}$.

Adicionalmente la Ley IV de ese mismo Título XVIII volvía a mencionar la prohibición de hacer prenda privada relativa al evento de la subasta judicial, salvo que lo autorizase el deudor o se tratase de tributos debidos al Señor o al Rey; y a recoger nuevamente los privilegios de caballeros y nobles - "que las debdas, que deban los Caualleros e otros qualesquier de las nuestras Cibdades e Villas e logares que mantoviesen cauallos e armas que les sean peyndrados los cauallos e armas de sus cuerpos"-.

Por su parte, la Ley I, del Título XVIII “De las prendas, é de los testamentos" prohibía que un acreedor prendase a su deudor por razón de los créditos que éste tuviese pendiente contra él por su sola autoridad, salvo que el deudor le hubiese concedido el poder necesario para ello. De ese modo, se prohibía la prenda extrajudicial, tan frecuente en la Alta Edad Media y arraigada como resultado de la influencia que en la Península Ibérica ejerció el Derecho Germánico. Adicionalmente, por medio de las leyes II y IV de ese mismo título, se estableció los bienes excluidos de dicha prohibición: pan, vino, pastos, bueyes, bestias para arar y labrar el campo, y demás

limitaciones o restricciones que limitaban drásticamente su posibilidad de aplicación; en tercer lugar las Siete Partidas; y en cuarto y último lugar, en defecto de todas las fuentes anteriores, los jueces debían acudir al Rey para que este corrigiese, interpretase o resolviese las controversias existentes en el ordenamiento jurídico mediante la redacción de una nueva ley. Reactivándose la vieja solución ofrecida por el Liber Iudiciorum y por el Fuero Real para la resolución de las controversias existentes en materia de prelación de fuentes jurídicas. GACTO FERNÁNDEZ E., ALEJANDRE GARCÍA, J.A. y GARCÍA MARÍN, J.M., Manual Básico de Historia del Derecho. Op., Cit., p. 197.

108 "Si el vendedor, o comprador de la cosa dixere que fue engannado en más de la meytad del derecho prescio, así como si el vendedor dixiere, que lo que valia dies, vendió por menos de cinco, ó el comprador dixiere que lo que valia dies, que dio por ello más de quince; mandamos que el comprador sea tenudo á cumplir el derecho prescio que valia la cosa, ó de la dejar al vendedor, tornandole el vendedor el prescio, que rescibio, é el vendedor debe tornar al comprador lo que mas rescibio de la meytad del derecho prescio, ó de tomar la cosa que vendio, é tornar el prescio que rescibio". CACHOFEIRO CEDENILLA, R., La tasación y las subastas de bienes inmuebles. Ed. SEAMER, Madrid, 1996, pp. 184-185.

${ }^{109}$ LUQUE TORRES, G., Las subastas judiciales. Aspectos civiles, procesales e hipotecarios. Op., Cit., p. 35 . 
frutos de la tierra, así como caballos y armas cuando sus propietarios fuesen caballeros deudores. Constituyéndose así un privilegio dependiendo de la naturaleza de la deuda y de la persona que la ostentaba ${ }^{110}$.

Por su parte, las Leyes de Toro - compuestas por ochenta y tres preceptos legales - fueron las encargadas de ordenar el Derecho civil de Castilla y reiterar el orden de prelación de fuentes del Derecho castellano que previamente había sido establecido por el Ordenamiento de Alcalá. En las leyes de Toro existían algunas normas de carácter procesal con incidencia directa sobre la enajenación en subasta judicial, entre las que destacaba la concesión del derecho de retracto o adquisición preferente a los parientes más próximos al deudor durante los nueve días siguientes a la aprobación del remate, adjudicándosele previa consignación del precio ofrecido como mejor postura y pagando al mejor postor en la enajenación en subasta judicial las costas que hubiese satisfecho — Ley LXX ${ }^{111}$ —. Si el pariente más próximo al acreedor sobre el que recaía ese derecho de adquisición preferente decidía no hacer uso del mismo, éste pasaba al siguiente pariente más próximo de forma gradual y sucesiva de acuerdo al orden de preferencia hasta alcanzar el límite del cuarto grado de parentesco - Ley LXXIII ${ }^{112}$-.

Es en este texto legal que nos ocupa, donde por primera, la Ley LXX introdujo la utilización del término remate; la Ley LXIII el establecimiento de un plazo de prescripción de diez años del derecho de ejecución y de veinte años de la acción personal; y la Ley LXIV la posibilidad de hacer valer las excepciones de pago, concediendo al deudor un plazo de diez días para probar los hechos que fundamentasen la excepción esgrimida ${ }^{113}$.

\section{La Nueva y la Novísima Recopilación}

Otros dos textos jurídicos del Derecho histórico español cuyo estudio es inexcusable y que están directamente relacionados con la institución procesal de la subasta judicial son: la Nueva Recopilación y la Novísima Recopilación ${ }^{114}$.

La Novísima Recopilación ${ }^{115}$ — sancionada por Real Cédula de 15 julio de 1805 por el rey Carlos IV - aumentó y completó las disposiciones relativas a la

\footnotetext{
110 Ibidem, p. 36.

111 "Sacar el pariente mas propinquo la cosa vendida de patrimonio por el tanto, aya tambien lugar, quando se vendiere en el almoneda pública, aunque sea por mandamiento del juez, y los nueve dias que dispone la Ley del fuero, se cuenten en este caso, desde del dia del remate, con tanto que consigue el que la saca el precio, y haga las otras diligencias que dispone la ley del fuero, y la ley del ordenamiento de Nieva, y ansi mismo aya de pagar al comprador las costas, y el alcabala, si las pagó el comprador, antes que la cosa así vendida le sea entregada".

${ }^{112}$ LLAMAS Y MOLINA, S., Comentario crítico, jurídico y literal a las ochenta y tres Leyes de Toro. Tomo II. Ed. Gaspar Editores, Madrid, 1875, pp. 337-387, y 428-457.

113 Ibidem, p. 498-499.

114 PÉREZ-VICTORIA DE BENAVIDES, M., Una Historia del Derecho. Ed. Gráficas la Alhambra, Granada, 2003, pp. 300, 327 y 328 -Nueva Recopilación-, y 301, 334 y 335 —Novísima Recopilación-.

115 La Novísima Recopilación se encontraba dividida en doce libros, conteniendo seis mil leyes, pragmáticas y autos, recogidos a través de la utilización de la técnica recopiladora. Libros I y II "Iglesia, Concordaos y su jurisdicción eclesiástica"; Libro III "Monarquía y administración de la Corona"; Libro IV "Consejo de Castilla"; Libro V "Organización de las Audiencias"; Libro VI "Régimen militar y fueros militares y académicos"; Libro VII "Gobierno civil de los pueblos"; Libro VIII "Ciencias y artes"; Libro
} 
institución procesal de la subasta judicial que previamente ya habían sido recogidas a través de la Nueva Recopilación ${ }^{116}$ — sancionada por Real Cédula de 14 de Marzo de 1567 por el rey Felipe II sobre la base del Ordenamiento de Montalvo, al corregir, aumentar y completar las disposiciones legales ulteriores a él, entre ellas las Leyes de Toro-

La regulación de la subasta judicial que encontramos en la Nueva Recopilación, y, por ende, también en la Novísima Recopilación destaca por su extensión. Dedica a su estudio un elevado número de leyes reguladoras de múltiples aspecto de la misma como por ejemplo ${ }^{117}$ :

- La prohibición de subastar ciertos bienes pertenecientes a determinadas personas. Quedaba prohibida la posibilidad de subastar judicialmente determinados bienes del deudor, bajo la pena de perder el objeto que había sido adquirido en la subasta judicial, cuando los bienes adquiridos en ella eran propiedad de personas pertenecientes al gremio de los tratantes - Ley XXVIII, del Título XIX, del Libro III-. En estos supuestos, para poder enajenar sus bienes en subasta judicial, era necesario la previa autorización del Juez, quién recababa información del gremio de los tratantes para determinar si existía o no fraude en la norma. Para garantizar su cumplimiento se exigía al Alcalde firmar el inventario de la subasta judicial, atestiguando que el bien objeto de la misma cumplía con los requisitos necesarios para poder ser enajenado en subasta judicial y que efectivamente se trataba del bien del deudor que previamente se había prendado - Ley II, del Título XL, del Libro VI-. Por su parte, la Ley II, del Título XL, del Libro VII, recogía a través de su contenido que bienes podían ser subastados judicialmente.

- Los requisitos que debían reunir los mandamientos de ejecución. Para proteger a los deudores ejecutados, se prohibía que los Alcaldes diesen mandamientos de ejecución en blanco o generales, debiendo hacer constar en ellos las personas contra las que se procedía y la fecha de celebración de la subasta judicial. En caso de no hacerse esto, el Alcalde quedaba obligado a devolver a su dueño los bienes que le habían sido prendados y a sancionar la subasta judicial con la nulidad de la misma Ley VI, del Título VIII, del Libro II; y Ley III, del Título XIV, del Libro V-. De forma complementaria a éstas, también se fijó qué personas no podían adquirir bienes por medio de la enajenación en subasta judicial. Se prohibía así, expresamente, que el Alcalde pudiese adquirir a través del desarrollo de la enajenación en subasta judicial cualquier bien integrado en la subasta judicial que ellos mimos presidiesen - Ley IV, del Título XIV, del Libro V-. Por último, relacionado con ésta misma cuestión, señalar

IX "Moneda, comercio y minas"; Libro X "Derecho Privado"; Libro XI "Procedimiento Civil”; Libro XII "Derecho Penal".

${ }^{116}$ La Nueva Recopilación, fruto de la voluntad de la reina Isabel I de Castilla de reducir la vasta legislación de los reinos de León y Castilla a un cuerpo legal breve y ordenado, constaba de nueve tomos -Libro I "Derecho Eclesiástico y Universidades"; Libro II "Derecho Público y organización judicial"; Libro III "Nuevas Audiencias de Sevilla, Galicia y Canarias"; Libro IV "Jurisdicción Real"; Libro V "Derecho Privado"; Libro VI "Materias diversas"; Libro VII "Régimen Municipal"; Libro VIII "Derecho Penal"; Libro IX "Hacienda y otras materias administrativas" - con aproximadamente unas cuatro mil leyes cada uno de ellos. CORONAS GONZÁLEZ, S.M., Manual de Historia del Derecho Español. $2^{\mathrm{a}}$ ed. Op., Cit., p. 284.

${ }^{117}$ Novísima Recopilación de las Leyes de España. Tomo II, Libros III, IV y V, y Tomo III, Libros VI y VII. Ed. Boletín Oficial del Estado, Madrid, 1976, pp. 167, 438 y 722. 
que los requisitos a cumplir por quienes decidían participar en el desarrollo de la subasta judicial quedaban regulados en la Ley XIV, del Título XXVIII, del Libro XI.

- La forma en la que debía practicarse el desarrollo de la subasta judicial —Ley XII, del Título XXVIII, del Libro XI ${ }^{118}$ _, así como, la publicidad que se le debía dar a ésta; el tiempo y los lugares donde debían leerse los pregones —el primero en el lugar de residencia del ejecutado, el resto donde residiese la audiencia-; y el emplazamiento de las partes para proceder directamente a la ejecución a través del mandamiento - Ley XIII, del Título XXVIII, del Libro XI-.

- Por último, señalar la prohibición expresa de que los Alcaldes ordenasen la emisión del remate sin tener conocimiento de todo el procedimiento judicial, especialmente, en aquellos supuestos carentes de mandamiento judicial previo - Ley XIV, del Título XXVIII, del Libro XI- También estaba tajantemente prohibido que los escribanos que acompañaban a los alguaciles hiciesen cualquier ejecución y diesen cartas judiciales de los bienes rematados y vendidos, al estar esta facultad reservada en exclusiva a los Escribanos de las Audiencias, por ser éstos los únicos que tenían la obligación y el pedimento de ejecución que habían de ir insertos en tales cartas. Adicionalmente, ante las irregularidades que se había llevado a cabo durante el desarrollo del procedimiento, se estableció que el alguacil ya no sería el encargado de aprobar el remate, independientemente de que existiese o no oposición, sino que la aprobación del remate tendría lugar por mandamiento del Juez una vez que se hubiese comprobado por éste último el cumplimiento de todas las normas reguladoras del procedimiento — Ley XV, de Título XXVIII, del Libro XI-.

\section{LA SUBASTA JUDICIAL EN LAS LEYES DE ENJUICIAMIENTO CIVIL}

Por último, y hasta poder llegar a la actualidad jurídica de nuestros días, desde la perspectiva del Derecho Procesal, la institución procesal de la subasta judicial se ha caracterizado por quedar regulada bajo de las modernas leyes —Códigos - de los siglos XIX, XX y XXI.

\footnotetext{
${ }^{118}$ LUQUE TORRES: “1. En primer lugar, sólo procede la ejecución sobre contratos públicos y otras escrituras, que llevan aparejada la ejecución, correspondiendo al juez comprobar si efectivamente procede la ejecución o no. 2. Comprobado este dato, el juez dictará mandamiento de ejecución sin citar a la parte ejecutada. 3. La ejecución sobre los bienes del ejecutado se llevará a cabo procediendo en primer lugar sobre los bienes muebles, en defecto de éstos sobre los inmuebles o raíces con fianzas de saneamiento, y en defecto de esas fianzas se tomará preso al deudor salvo que no se pueda conforme a las leyes. 4. Si la ejecución se realiza sobre muebles por existir éstos en el patrimonio del deudor, se anunciará por pregones la subasta por tiempo de nueve días, de tres en tres días cada pregón. Si los bienes fueren inmuebles o raíces, se anunciará por tiempo de veintisiete dias, de nueve en nueve días cada pregón. 5. Anunciada la venta pública a través de los pregones en los plazos señalados antes, se procederá a citar al deudor para el remate. Si no fuere hallado en su casa, se le citará a través de su esposa, familiar, criado, o vecino más cercano. 6. Dentro de los tres días siguientes a la citación, el deudor podrá oponerse haciendo valer alguna legítima excepción conforme a la Ley. 7. Si transcurrido este plazo el deudor no hace uso de este derecho oponiéndose, el juez ordenará hacer el remate pagándose asi la deuda, sin perjuicio de cualquier apelación”. LUQUE TORRES, G. Las subastas judiciales. Aspectos civiles, procesales e hipotecarios, Óp., Cit., p.40. "Por ende mandamos, que en todos los mandamientos exutorios, que de aquí en adelante se dieren en los dichos Adelantamientos, se mande, que la parte sea emplazada para el remate, y que el tal emplazamiento se haga después de los pregones, como se requiere de Derecho, y que después, un día ates que se haga del remate; y que si hubiere oposición después de ella, no se dé otro mandamiento para el dicho remate”.
} 
La codificación española del Derecho Procesal Civil permitió acabar con el complejo sistema de jurisdicciones especiales del Antiguo Régimen que planteaban numerosos problemas de competencia y, concretamente en nuestro sistema, con el desorden en los títulos procesales contenidos en el sistema jurídico que había sido establecido previamente por la Novísima Recopilación ${ }^{119}$.

\section{La Ley de Enjuiciamiento Civil de 1855}

El 30 de septiembre de 1853, siendo Ministro de Gracia y Justicia D. José de Castro y Orozco - Marqués de Gerona-, se publicó la Instrucción del Procedimiento Civil con respecto a la Real Jurisdicción y Ordenanza con el deseo de poner fin a los abusos y dilaciones innecesarias del procedimiento ordinario. Siendo derogada por los progresistas once meses después de su promulgación ${ }^{120}$. Resultado de esa situación, el Gobierno ordenó la redacción de un código completo de instrucción que dio lugar a la Ley de Bases, de 13 de mayo, de 1855 y posteriormente a la Ley de Enjuiciamiento Civil, de 5 de octubre, de 1855. Sin embargo, la comisión formada para su elaboración, en lugar de apostar por la introducción de las reformas necesarias en el procedimiento, se mantuvo fiel a la línea de los textos patrios - Siete Partidas - y, como resultado, pese a su vigencia durante veintiséis años, la Ley ya nació obsoleta y con poco futuro. En consecuencia, y tras el fallido intento de reforma de la Ley de Enjuiciamiento Civil de 1870, el Ministro de Gracia y Justicia encargó a la Comisión de Codificación presidida por entonces por Manuel Alonso Martínez - la elaboración de un estudio sobre las modificaciones que debían introducirse en el texto original de la Ley. Redactándose así, una Ley de Bases sobre la estructura original de la Ley de Enjuiciamiento Civil de 1855 —respetándola, pero introduciendo disposiciones ulteriores y un procedimiento más simple y abreviado - que tras ser revisada, finalmente, fue aprobada como la Ley de Enjuiciamiento Civil, de 3 de febrero, de $1881^{121}$. Compuesta por dos mil ciento ochenta y dos artículos, divididos en tres libros: Libro I "Disposiciones comunes"; Libro II "Jurisdicción contenciosa"; Libro III "Jurisdicción Voluntaria".

La Ley de Enjuiciamiento Civil de 1855 regulaba las subastas judiciales en diferentes partes de su articulado, concretamente a través de los arts. 972 y ss. procedimiento de apremio — ; los arts. 1.374 a 1.379 — subastas judiciales voluntarias; y por último, los arts. 1401 a 1.413 -la preceptiva autorización judicial para proceder a la venta de los bienes de menores e incapacitados ${ }^{122}$.

Como nota especialmente significativa de la Ley de Enjuiciamiento Civil de 1855, PRIETO CASTRO ${ }^{123}$ señalaba que "con anterioridad a la Ley de Enjuiciamiento Civil de 1855 no existían diferencias sustanciales entre la ejecución de sentencias y la de los demás títulos ejecutivos, de modo que el denominado juicio ejecutivo era el

\footnotetext{
119 PÉREZ BUStamante, R., Historia del Derecho Español. Las Fuentes del Derecho. Op., Cit., p. 309.

${ }^{120}$ PRIETO CASTRO, L., "La instrucción del Marqués de Gerona". Revista General de Legislación y Jurisprudencia. XXV, pp. 114-133 Ed. Reus, Madrid, 1953, p. 193.

121 SÁNCHEZ-ARCILLA BERNAL, J., Historia de las Instituciones Político-Administrativas Contemporáneas (1808-1975). Ed. Dykinson, Madrid, 1994, pp. 524-525.

122 GÓMEZ DE LA SERNA, P., Motivos de las variaciones principales que ha introducido en los procedimientos la Ley de Enjuiciamiento Civil. Ed. Imprenta de la Revista de Legislación, Madrid, 1857, pp. 183,252 y 258.

${ }^{123}$ PRIETO CASTRO, L., Derecho Procesal Civil II. Ed. Aranzadi, Pamplona, 1982, pp. 182-195.
} 
común de todos los preceptos que regulaban el proceso de ejecución. Aprobada la Ley de Enjuiciamiento Civil de 1855, se extrajo el título de sentencia judicial del capítulo dedicado al juicio ejecutivo y a regular su forzoso cumplimiento de forma separada, apareciendo la sentencia como el primer título que llevaba aparejada ejecución. Sin embargo, el legislador olvidó extraer las normas comunes al proceso de ejecución, especialmente las referentes al proceso de apremio, causando una gran dispersión en los preceptos sobre la ejecución forzosa, y por ende sobre la subasta judicial. Dando traslado de este error sistemático —ubicar el núcleo fundamental de las normas referentes a la ejecución forzosa (procedimiento de apremio) en el título dedicado el juicio ejecutivo, en lugar de encuadrarlas en el capítulo dedicado a las sentencias firmes de condena - a la Ley de Enjuiciamiento Civil". Ese error sistemático del legislador junto con otras muchas circunstancias motivó, finalmente, la necesidad de proceder a la elaboración y posterior aprobación de la Ley de Enjuiciamiento Civil, de 3 de octubre, de 1881. Ley que apoyada en un conjunto de reformas legislativas estuvo vigente durante 119 años, hasta el año 2000. Cuando tras la oportuna reforma fue aprobada la Ley $1 / 2000$, de 7 de enero, de Enjuiciamiento Civil.

\section{La Ley de Enjuiciamiento Civil de $\mathbf{1 8 8 1}$}

El error sistemático de la Ley de Enjuiciamiento Civil de 1855 al que antes hicimos referencia, quedó también plasmado en la Ley de Enjuiciamiento Civil de 1881 al recoger las normas en materia de ejecución en el Título VIII, Libro II, dedicado a la "Ejecución de condenas que tengan por causa una sentencia u otro título equiparado a ellas", y Título XV, también del Libro II, dedicado al "Juicio ejecutivo". Estableciendo dentro de este último título dos secciones: el procedimiento ejecutivo —arts. $1.429 \mathrm{y}$ ss. - y el procedimiento de apremio; y dentro de éste último, la subasta judicial —arts. 1481 a 1.532 - . De ese modo, "el procedimiento de apremio y el de la subasta judicial aparecían como una fase subsiguiente del juicio ejecutivo, cuando en realidad constituyen en nuestro Derecho parte integral del proceso de ejecución propiamente dicho. Pues el procedimiento de apremio sirve no solo para hacer efectiva la sentencia de remate, sino también toda la sentencia de condena al pago de una cantidad determinada de dinero" 124 . Es por todo ello, por los que las normas relativas a la ejecución han sido duramente criticadas, no solo por su falta de coherencia sistemática, sino también por su imprecisión terminológica, así como por la ausencia de un título o libro específico dentro de la Ley de Enjuiciamiento Civil en el que ubicar cualquier tipo de ejecución ${ }^{125}$.

De este modo, la Ley de Enjuiciamiento Civil de 1881, regulaba la figura de la subasta judicial por medio de los siguientes títulos:

- $\quad$ El juicio de abintestato — arts. 959 a 1.035 -

- $\quad$ Del concurso de acreedores y de la quiebra - arts. 1.156 a 1.317, y arts. 1.318 a 1.396 , respectivamente-.

- Las subastas judiciales forzosas. El procedimiento de apremio — arts. 1.481 a 1.531 -

${ }^{124}$ MORAL MORO, M‥J., La subasta judicial de bienes inmuebles, Op., Cit., pp. 37-38.

${ }^{125}$ MONTERO AROCA, J., Perfeccionamiento del sistema de ejecución singular. La indefensión del ejecutante. Estudios de Derecho Procesal. Ed. Bosch, Barcelona, 1981, pp. 275 y ss.; MOLINER TAMBORERO G., "La ejecución singular proyectada en la reforma de la Ley de Enjuiciamiento Civil". Revista del Poder Judicial. Ed. Consejo General del Poder Judicial, Madrid, 1984, pp. 99 y ss. 
- $\quad$ La venta de bienes de menores e incapacitados — arts. 2.011 a 2.030 -

- $\quad$ Las subastas judiciales voluntarias — arts. 2.048 a 2.055-.

- $\quad$ Ventas judiciales de los depósitos mercantiles — arts. 2.124 a 2.125-

art. 2.161-.

Enajenación y apoderamiento de efectos mercantiles en casos urgentes -

Como antes indicamos, la Ley de Enjuiciamiento Civil de 1881 estuvo vigente durante 119 años, hasta el año 2000. Cuando tras la oportuna reforma fue aprobada la Ley 1/2000, de 7 de enero, de Enjuiciamiento Civil. Durante esos 119 años, la Ley de Enjuiciamiento Civil de 1881 fue objeto de diversas modificaciones, destacando de forma significativa y a los efectos del presente trabajo:

Enjuiciamiento Civil

La Ley 34/1984, de 6 de agosto, de Reforma Urgente de la Ley de

Con esta reforma, el legislador pretendía solventar los retrasos que existían en la justicia como resultado de la falta de medios coactivos y la presencia de rigurosos formalismos, al tiempo de tratar de hacer realidad el derecho a la tutela judicial efectiva consagrada en el art.24 de la Constitución Española - CE - mediante la implantación de un procedimiento de apremio más eficaz y menos costoso ${ }^{126}$.

A través de ésta reforma, se produjeron grandes e importes cambios en materia de apremio: la obtención de mayores rendimientos, la reducción del esfuerzo del deudor sin que ello influyese en el cumplimiento de su obligación, y la terminación de todo el tráfico jurídico que envolvía al mundo de las subastas judiciales. Sin embargo, VÁZQUEZ SOTELO y FAIREN GUILLÉN ${ }^{127}$, hacen hincapié en la incapacidad de esta misma reforma procesal para resolver la cuestión relativa a "la vigencia de los principios de subsistencia y transmisión de cargas de las ejecuciones hipotecarias, en relación con el sistema de liquidación o purga de cargas temporales regulado en la LEC" y "la destrucción de uno de los errores más graves de sistemática de la LEC de 1855: el dédalo existente entre el juicio ejecutivo y la ejecución forzosa", respectivamente.

La Ley 10/1992, de 30 de abril, de Reforma Urgente de la Ley de Enjuiciamiento Civil.

El procedimiento de apremio se vuelve a modificar con la reforma de la LEC 1881 por la Ley $10 / 1992^{128}$. En virtud de esta reforma, además de eliminar la

\footnotetext{
${ }^{126}$ Procediendo para ello a la modificación de todos los artículos relacionados con ésta misma cuestión arts. $1.481,1.488,1.495,1.499$ y $1.500,1.503$ y $1.504,1.506,1.507,1.508$, y $1.513-$ y a la incorporación de dos nuevos párrafos — segundo y tercero- a la anterior redacción del art.1481 LEC. PÁSTOR LÓPEZ, M., "Ley 34/1984, de 6 de agosto, de reforma urgente de la Ley de Enjuiciamiento Civil”. Revista de Derecho Procesal. № 1, pp. 121-168 Ed. Revista Iberoamericana de Derecho Procesal, Madrid, 1985, pp. 121 y ss.

${ }^{127}$ VÁZQUEZ SOTELO, J.L. (Coord.), Comentarios a la Reforma de la Ley de Enjuiciamiento Civil. Ed. Reus, Madrid, 1985, pp. 739-740; FAIRÉN GUILLÉN, V., Juicio de menor cuantía, casación y otros aspectos fundamentales de la Ley de 6 de Agosto de 1984. La Ley de Reforma Urgente de la Ley de Enjuiciamiento Civil. Ed. Civitas, Madrid, 1985, p. 315.

${ }^{128}$ Una reforma de carácter parcial y urgente encaminada a adaptar progresivamente las normas procesales a las necesidades que la praxis jurídica muestra como ineludibles. Teniendo como objetivos esenciales el de aprovechar los recursos de la justicia a fin de procurar que ésta se imparta de la forma más rápida y eficaz posible, de acuerdo a las exigencias del art.24 de la Constitución Española.
} 
posibilidad de cesión del remate para quien no fuese ejecutante, se encomendó la celebración de la subasta judicial al Secretario Judicial - ahora denominado Letrado de la Administración de Justicia (LAJ) - y se estableció que el documento público era título inscribible, al tiempo que se adaptaron los preceptos de la Ley de Enjuiciamiento Civil a lo dispuesto por la legislación hipotecaria ${ }^{129}$.

Pese a ser calificada por un gran sector de la Doctrina como positiva DAMIÁN MORENO y FERNÁNDEZ LÓPEZ ${ }^{130}$, entre otros muchos-, lo cierto es que no introduce cambios sustanciales en lo referente al procedimiento de apremio ni a la ejecución. De ahí que, CORTÉS DOMÍGNUEZ y FRANCO ARIAS ${ }^{131}$ consideraran que con esta reforma procesal se desaprovechó "una gran ocasión para reformar verdaderamente el proceso de ejecución y satisfacer y proteger el derecho a la tutela judicial efectiva reconocida en el art.24 de la CE. Habiendo sido necesario cambios sustanciales para potenciar su eficacia como fase del proceso".

Por su parte, otros autores como SERRA DOMÍNGUEZ y MONTERO AROCA $^{132}$ también criticaron esta reforma procesal centrándose en su carácter parcial —antes referido - . Ambos autores defienden que "no habiendo superado el trauma que supuso la reforma procesal de 1984, no parece oportuno abordar una reforma parcial, que puede suponer no solo una crisis de nuestras instituciones, sino que además no se cumpla el contenido del art.24.1 de la CE referente a la tutela judicial efectiva".

Más tarde en el año 2000, siendo Ministra de Justicia Dña. Margarita Mariscal de Gante y Secretario de Estado de Justicia D. José Luis González Montes, se aprobó la Ley 1/2000, de 7 de enero, de Enjuiciamiento Civil. Esta última vino a derogar la Ley de Enjuiciamiento Civil de 3 de Febrero de 1881, aunque no en su totalidad, pues conforme a su Disposición Derogatoria Única - coincidente en lo relativo al contenido con la Disposición Final (art.2181) de la Ley de Enjuiciamiento Civil de 1881 - se establecía la derogación de la Ley de Enjuiciamiento Civil, aprobada por el Real Decreto de 3 de Febrero de 1881, pero con las siguientes excepciones:

- $\quad$ Se dispuso que los Títulos XII y XIII del Libro II y el Libro III de la Ley de Enjuiciamiento Civil de 1881 quedarían en vigor hasta la vigencia de la Ley Concursal y de la Ley sobre Jurisdicción Voluntaria, respectivamente. Todo ello a excepción del art.1827 y de los arts. 1880 a 1900, derogados automáticamente.

\footnotetext{
${ }^{129}$ Procediéndose a reformar, cambiar o alterar el contenido de los arts.1. 489, 1.490, 1.499, 1.500, 1.503, $1.509,1.511,1.512,1.514,1.515,1.516,1.518$ y $1.519-$, y dejar sin contenido los arts. 1.516 y 1.517 .

${ }^{130}$ Entre otros a DAMIAN MORENO, J., La reforma procesal civil, penal y administrativa de 1992. Estudio sistemático de la Ley 10/1992, de 30 de Abril, de Medidas Urgentes de Reforma Procesal. Ed. COLEX, Madrid, 1992, pp. 69 y ss.; también, en el mismo sentido, FERNÁNDEZ LÓPEZ, J.M., "La Reforma procesal en las ejecuciones", en FERNÁNDEZ LÓPEZ, J.M. e ILLESCAS RUS, A.V. (Dir.), La Reforma Procesal Civil por la ley 10/1992. Criterios prácticos de interpretación. Op., Cit., p. 311 y SS.

${ }^{131}$ CORTES DOMÍNGUEZ, V., Comentarios sobre la reforma procesal. Ley 10/92, de 30 de Abril. Ed. FORUM, Oviedo, 1992, p. 132 y ss.; y, por otro lado, FRANCO ARIAS, J., La reforma de los Procesos Civiles. Comentarios a la Ley 10/1992, de Medidas Urgentes de Reforma Procesal. Ed. Civitas, Madrid, 1993, p. 160.

132 SERRA DOMÍNGUEZ, M., "Notas al Anteproyecto de Actualización de la LEC". Justicia. Ed. Bosch, Barcelona, 1990, p. 777; MONTERO AROCA, J., Ensayos de Derecho Procesal. Ed. Bosch, Barcelona, 1996, p. 279.
} 
- Hasta la entrada en vigor de las referidas Leyes, se acordó que los números $1 .^{\circ}$ y $5 .^{\circ}$ del art. 4 ; los números $1 .^{\circ}$ y $3 .^{\circ}$ del art. 10 ; y las reglas $8 .^{\mathrm{a}}, 9 .^{\mathrm{a}}, 16 .^{\mathrm{a}}$, 17. $.^{\mathrm{a}}, 18 .^{\mathrm{a}}, 19 .^{\mathrm{a}}, 22 .^{\mathrm{a}}, 23 .^{\mathrm{a}}, 24 .^{\mathrm{a}}, 25 .^{\mathrm{a}}, 26 .^{\mathrm{a}}$ y $27 .^{\mathrm{a}}$ del art. 63 de la Ley de Enjuiciamiento Civil de 1881 también quedarían en vigor. Se estableció que hasta que no entrase en vigor la Ley Concursal, los incidentes que surgiesen en el seno de procesos concursales se regirían por lo dispuesto en la presente Ley para la tramitación de incidentes. En este mismo sentido, fijaron que mientas no entrase en vigor la Ley de Jurisdicción Voluntaria, las referencias al procedimiento contencioso procedente contenidas en el Libro III se entenderían hechas al juicio verbal.

- Se interpretó que el Título I del Libro II y el art.11 —sobre la conciliación-, y la sección $2^{\mathrm{a}}$ del Título IX del Libro II — sobre declaración de herederos abintestato - continuarían vigentes hasta la entrada en vigor de la regulación de ambas materias en la Ley sobre Jurisdicción Voluntaria.

- $\quad$ Por último, se dispuso que los arts. 951 a 958 — sobre eficacia en España de sentencias dictadas por tribunales extranjeros - quedarían en vigor hasta la vigencia de la Ley sobre cooperación jurídica internacional en materia civil.

Con la LEC del año 2000, se hizo patente la necesidad de abandonar el método de las reformas parciales y apostar por la creación de una nueva Ley Procesal Civil española capaz de mejorar la impartición de la justicia en el orden jurisdiccional civil a la vez que acoger y vertebrar la tutela judicial efectiva reconocida en el art.24 de nuestra Constitución sin mermas de garantías judiciales y procesales. Esa nueva Ley de Enjuiciamiento Civil del año 2000 estableció dentro del Título IV, del Libro III, un Capítulo IV - arts.634 al 680 - que contemplaba en exclusiva el procedimiento de apremio y dentro de éste la gran novedad del momento: una única subasta judicial, con matices o peculiaridades en función del tipo de bien objeto de la misma; mueble o inmueble.

La nueva Ley de Enjuiciamiento Civil, conservando su experiencia jurídica de más de un siglo, fue capaz finalmente de adaptarse a los nuevos cambios sociales para dar respuesta a numerosos problemas de imposible o difícil solución con la anterior Ley de Enjuiciamiento Civil. Consiguiendo, bajo su genuino título ejecutivo del Libro III "De la ejecución forzosa y de las medidas cautelares", imponer un solo procedimiento de ejecución dentro del cual tenía cabida no solo la ejecución judicial sino también la contractual, así como la ejecución forzosa común y la de garantías hipotecarias —a la que dedica especial atención al consagrar un grupo de normas orientadas a la protección del acreedor y a regular problemas y situaciones que hasta ahora apenas se habían tomado en consideración o que habían sido ignoradas legalmente-. Todas las cuestiones relativas al procedimiento de ejecución — partes, sujetos intervinientes, competencia, recursos etc. - también quedaron recogidas dentro de ese mismo libro tercero antes señalado.

De forma ya más concreta, el Capítulo IV "Del procedimiento de apremio", del Título IV "De la ejecución dineraria" del Libro III "De la ejecución forzosa y de las medidas cautelares" asumió el encargo de contemplar en exclusiva la regulación del procedimiento de apremio, configurando una nueva y única subasta judicial rodeada de disposiciones encaminadas a lograr un resultado más satisfactorio para el deudor y la reducción de los costes asociados al procedimiento, así como la apertura a vías 
alternativas de enajenación forzosa que permitían agilizar la realización forzosa y mejorar su rendimiento a través de convenios entre el ejecutante y ejecutado, posteriormente aprobados judicialmente. E imposibilitando que a instancia del ejecutante o del ejecutado y cuando las circunstancias del bien así lo aconsejasen, el tribunal pudiese acordar la enajenación forzosa del bien a través de personas o entidades especializadas en la materia, al margen de la subasta judicial ${ }^{133}$.

Finalmente, la Ley de Enjuiciamiento Civil 1/2000 ha sido recientemente reformada tras la aprobación de las Leyes 19/2015, de 13 de Julio, de medidas de reforma administrativa en el ámbito de la Administración de Justicia y del Registro Civil y 42/2015, de 5 de octubre, de reforma de la Ley 1/2000, de 7 de enero, de Enjuiciamiento Civil. Dicha reforma, en materia de ejecución y de forma ya más concreta en materia de subastas judiciales, destaca por el establecimiento de un nuevo sistema de subastas judiciales forzosas caracterizado por el hecho de que desde el 15 de octubre de 2015 todas las subastas judiciales de carácter forzoso que se celebran en nuestro país tienen lugar de forma telemática, electrónicamente, vía Internet a través del Portal Electrónico de Subastas Judiciales y Administrativas creado dentro de la Agencia Estatal Boletín Oficial del Estado -AEBOE-. Se acaba, de este modo, con el tradicional sistema de subastas judiciales presenciales existentes hasta el momento, siendo sustituido por el nuevo sistema de subastas judiciales forzosas electrónicas.

\section{IDEAS FINALES}

La institución procesal de la subasta judicial no es una creación del derecho moderno, sino más bien todo lo contrario, una figura jurídica cuyo origen lo encontramos en la etapa más primitiva de toda la esfera jurídica: en el Derecho Romano. De este modo, y pese a la existencia de ciertas diferencias, podemos afirmar que la bonorum venditio constituye el antecedente de la actual institución procesal de la subasta judicial. Un medio, un instrumento de ejecución forzosa dividido en dos etapas: el embargo y el apremio — realización forzosa - de los bienes muebles e inmuebles que previamente han sido embargados del patrimonio del ejecutado. En ambos modelos en el romano y en el actual-, naturalmente adaptados a la realidad económica, social y jurídica de cada momento histórico, encontramos un conjunto de actuaciones de carácter previo orientadas a la preparación del desarrollo de la subasta judicial como por ejemplo lo son la publicidad de la convocatoria de la subasta judicial y el establecimiento de un contenido mínimo de la información ofrecida con relación al desarrollo de la subasta judicial, entre otros muchos. De ahí, que con total rotundidad, podamos afirmar que la subasta judicial integrante de los actuales procesos de ejecución forzosa, fue introducida a través de la antiquísima figura jurídica de la pignus in causa iudicati captum.

La ejecución forzosa, al proceder en virtud de un título del que directa o indirectamente resulta el deber de entregar una cantidad de dinero líquida y determinada, persigue el propósito de satisfacer el derecho de crédito del ejecutante a través de multas coercitivas en forma de apremios que recaen directamente sobre el patrimonio del ejecutado. Sin embargo, frente a lo sucedido en la etapa romana - donde el incumplimiento de las obligaciones crediticias se traducía en la represión física y no patrimonial del ejecutado-, en los actuales sistemas de ejecución forzosa —adaptados adecuadamente a los nuevos sistemas de valores, garantías y derechos - la mencionada

${ }^{133}$ MORAL MORO, M..J., La subasta judicial de bienes inmuebles, Op., Cit., pp. 52-53. 
coacción ejecutiva no se ejerce directamente sobre la persona del deudor o ejecutado sino sobre el conjunto de bienes muebles e inmuebles que integran su patrimonio. Somos testigos pues de una tendencia hacia la progresiva humanización de las penas y castigos que recaen sobre la persona del deudor, evolucionando desde el empleo de instrumentos propiamente punitivos sobre la vida o la libertad del propio deudor hacia su sustitución por un sistema de sanciones de naturaleza patrimonial, donde la responsabilidad personal subsidiaria, pese a continuar estando presente, tiende a desaparecer. Subsistiendo, únicamente, la responsabilidad patrimonial del deudor ejecutado que pierde sus connotaciones punitivas para asumir funciones resarcitorias o reparadoras.

\section{BIBLIOGRAFÍA}

ÁlVAREZ SUÁREZ, U., Curso de Derecho Romano, Tomo I. Introducción, Cuestiones Preliminares, Derecho Procesal Civil Romano. Ed. Revista de Derecho Privado, Madrid, 1955.

ARANGIO RUIZ, V., Instituciones de Derecho Romano. Ed. Depalma, Buenos Aires, 1986.

ARIAS RAMOS, J. y ARIAS BONET, J.A., Derecho Romano, Tomo I. $18^{\mathrm{a}}$ ed. Ed. Revista de Derecho Privado, Madrid, 1986.

AZARA, A. y EULA, E., Novissimo Digesto Italiano. Tomo VII. Ed. Unione Tipográfico-Editrice Torinese, Ristampa, 1979.

BETANCOURT SERNA, F., "Sobre la pretendida transmisibilidad de los interdictos". Revista Anuario de Historia del Derecho Español. No 53, pp. 46-77. Ed. Ministerio de Justicia y Boletín Oficial del Estado, Madrid 1983.

CAMACHO EVANGELISTA, F., Derecho privado romano. $2^{\mathrm{a}}$ ed. Ed. Técnica Avicam, Granada, 2016.

CAPILLA RONCERO, $\mathrm{F}$., La responsabilidad patrimonial universal y el fortalecimiento de la protección del crédito. Ed. Fundación Universitaria de Jerez, Jerez, 1989.

CASINOS MORA, F.J., Derecho Privado Romano. Ed. Dykinson, Madrid, 2016.

CACHOFEIRO CEDENILLA, R., La tasación y las subastas de bienes inmuebles. Ed. SEAMER, Madrid, 1996.

CORONAS GONZÁLEZ, S.M., Manual de Historia del Derecho Español. $2^{\mathrm{a}}$ ed. Ed. Tirant lo Blanch, Valencia, 1999.

CORTES DOMÍNGUEZ, V., Comentarios sobre la reforma procesal. Ley 10/92, de 30 de Abril. Ed. FORUM, Oviedo, 1992. 
DAMIAN MORENO, J., La reforma procesal civil, penal y administrativa de 1992. Estudio sistemático de la Ley 10/1992, de 30 de Abril, de Medidas Urgentes de Reforma Procesal. Ed. COLEX, Madrid, 1992.

DE FRANCISCI, P., Síntesis histórica del Derecho Romano. Ed. Revista de Derecho Privado, Madrid, 1954.

D’ORS J.A., Derecho Privado Romano. 10ª ed. Ed. Eunsa, Pamplona, 2004.

ESCUDERO, J.A., Curso de Historia del Derecho. Fuentes e Instituciones PolíticoAdministrativas. Ed. Solana e Hijos, A.G., S.A.U., Madrid, 2012.

FAIRÉN GUILLÉN, V., Juicio de menor cuantía, casación y otros aspectos fundamentales de la Ley de 6 de Agosto de 1984. La Ley de Reforma Urgente de la Ley de Enjuiciamiento Civil. Ed. Civitas, Madrid, 1985.

FERNÁNDEZ BARREIRO A. y PARICIO, J., Fundamentos de Derecho Patrimonial Romano. Ed. Centro de Estudios Ramón Areces, S.A., Madrid, 1991.

FERNÁNDEZ DE BUJÁN, A., Jurisdicción y Arbitraje en Derecho Romano. Ed. Iustel, Madrid, 2006.

FERNÁNDEZ ESPINAR, R., Antología de textos jurídicos históricos. Ed. TAT, Granada, 1990.

FRANCO ARIAS, J., La reforma de los Procesos Civiles. Comentarios a la Ley 10/1992, de Medidas Urgentes de Reforma Procesal. Ed. Civitas, Madrid, 1993.

FUENTESECA, P., Investigaciones de Derecho Procesal Romano. Ed. Studia Iris Romani Salmanticensia, Salamanca, 1969.

FUENTESECA, P., Derecho Privado Romano. Ed. Gráficas E. Sánchez, Madrid, 1978.

GACTO FERNÁNDEZ E., ALEJANDRE GARCÍA, J.A. y GARCÍA MARÍN, J.M., Manual Básico de Historia del Derecho. Ed. Laxes, S.L. Fotocomposición, Madrid, 1999.

GÁMEZ MONTALVO, Ma.F., GARRIDO ARREDONDO, J., LÓPEZ NEVOT, J. A., y SAINZ GUERRA, J., Textos para una Historia del Derecho Español. Ed. Comares, Granada, 1994.

GARCIA ESCOBAR, G.A., "El tratamiento de los créditos concursales y el principio de la par conditio creditorum". Revista Internacional de Doctrina y Jurisprudencia. $\mathrm{N}^{\mathrm{o}}$ 5, Ed. Universidad de Almería, Almería, 2014.

GARCÍA GARRIDO, M.J., Casuismo y Jurisprudencia Romana-Responsa-. Acciones y Casos. $4^{\mathrm{a}}$ ed. Ed. Ediciones Académicas, Madrid, 2008.

GARCÍA GARRIDO, M.J., Derecho privado romano. Caso. Acciones. Instituciones. $17^{\mathrm{a}}$ ed. Ed. Ediciones Académicas, Madrid, 2008. 
GARCÍA GARRIDO, M.J., Derecho Privado Romano. Casos-Acciones-Instituciones. $20^{\mathrm{a}}$ ed. Ed. Ediciones Académicas, Madrid, 2015.

GARCÍA GOYENA, F. y AGUIRRE, J., Febrero Reformado. Tomo I. $4^{\mathrm{a}}$ ed. Imprenta y Librería de Gaspar Roig Editores. Madrid, 1852.

GAYO, Instituciones jurídicas. Editorial Iberia S.A. Barcelona, 1965, comentario IV, 12.

GÓMEZ DE LA SERNA, P., Motivos de las variaciones principales que ha introducido en los procedimientos la Ley de Enjuiciamiento Civil. Ed. Imprenta de la Revista de Legislación, Madrid, 1857.

GUITÉRREZ FERNÁNDEZ, B., Estudios de Derecho Civil. Tomo V. $1^{\text {a }}$ ed. Editorial Lex Nova, Madrid, 1869.

IGLESIAS REDONDO, J., Derecho Romano. Historia e Instituciones. $18^{\mathrm{a}}$ ed. Sello Editorial, Barcelona, 2010.

IGLESIAS SANTOS, J., Derecho Romano. 16ª ed. Ed. Ariel, Barcelona, 2007.

LÓPEZ, G., Las Siete Partidas. Partidas I y II, Partidas III y IV, y Partidas V, VI y VII. Impreso por Andrea de Portonaris, Salamanca, 1555.

LUQUE TORRES, G., Las subastas judiciales: aspectos civiles, procesales e hipotecarios. Ed. Comares, Granada, 1999.

LLAMAS Y MOLINA, S., Comentario crítico, jurídico y literal a las ochenta y tres Leyes de Toro. Tomo II. Ed. Gaspar Editores, Madrid, 1875.

MARTíNEZ AlCUBILlA, M., Colección de Códigos y Leyes de España. Códigos antiguos. Tomo I. Ed. Roig, Madrid, 1865.

MARTÍNEZ DÍEZ, G., "El Fuero Real y el Fuero de Soria". Anuario de Historia del Derecho Español. No 39, Ed. Ministerio de Justicia y Boletín Oficial del Estado, Madrid, 1969.

MOLINER TAMBORERO G., "La ejecución singular proyectada en la reforma de la Ley de Enjuiciamiento Civil”. Revista del Poder Judicial. Ed. Consejo General del Poder Judicial, Madrid, 1984.

MONTERO AROCA, J., Perfeccionamiento del sistema de ejecución singular. La indefensión del ejecutante. Estudios de Derecho Procesal. Ed. Bosch, Barcelona, 1981.

MONTERO AROCA, J. Ensayos de Derecho Procesal. Ed. Bosch, Barcelona, 1996.

MURGA FERNÁNDEZ, J.P., “Antecedentes históricos de la venta en pública subasta”. Revista Anales de Derecho. Vol. 33, No 1, Ed. Universidad de Murcia, Murcia, 2015. 
Novísima Recopilación de las Leyes de España. Tomo II, Libros III, IV y V, y Tomo III, Libros VIy VII. Ed. Boletín Oficial del Estado, Madrid, 1976.

ORTEGA CARRILlO DE ALBORNOZ, A., Derecho Privado Romano. Ed. Ediciones del Genal, Málaga, 2010.

PANERO GUTIÉRREZ, R., Derecho Romano. $4^{\mathrm{a}}$ ed. Ed. Tirant Lo Blanch, Valencia, 2008 .

PANERO GUTIÉRREZ, R., Epitome de Derecho Romano. Ed. Tirant Lo Blanch, Valencia, 2010.

PÁSTOR LÓPEZ, M., "Ley 34/1984, de 6 de Agosto, de reforma urgente de la Ley de Enjuiciamiento Civil". Revista de Derecho Procesal. No 1, Ed. Revista Iberoamericana de Derecho Procesal, Madrid, 1985.

PÉREZ ÁLVAREZ, M.P., "Las ventas por subasta en la esfera del Derecho Público". Revista General de Derecho Romano. N 14. Ed. Iustel, Madrid, 2010.

PÉREZ BUSTAMANTE, R., Historia del Derecho Español. Las Fuentes del Derecho. Ed. Dykinson, Madrid, 1997.

PÉREZ-VICTORIA DE BENAVIDES, M. Una Historia del Derecho. Ed. Gráficas la Alhambra, Granada, 2003.

PRIETO CASTRO, L., "La instrucción del Marqués de Gerona". Revista General de Legislación y Jurisprudencia. XXV, pp. 114-133 Ed. Reus, Madrid, 1953.

PRIETO CASTRO, L., Derecho Procesal Civil II. Ed. Aranzadi, Pamplona, 1982.

PRIETO-CASTRO Y FERRÁNDIZ, L. Derecho Procesal Civil. $3^{\mathrm{a}}$ ed. Ed. Tecnos, Madrid.

RASCÓN GARCÍA, C., Síntesis de Historia e Instrucciones de Derecho Romano. $4^{\mathrm{a}}$ ed. Ed. Tecnos, Madrid, 2011.

ROBLES VELASCO, L.M., Unidades didácticas de Derecho Romano Privado. $2^{\mathrm{a}}$ ed. Ed. Editorial Técnica Avicam, Granada, 2015.

SÁNCHEZ-ARCILLA BERNAL, J., Historia de las Instituciones PoliticoAdministrativas Contemporáneas 1808-1975. Ed. Dykinson, Madrid, 1994.

SÁNCHEZ, G., "Para la historia de la redacción del antiguo derecho territorial castellano". Anuario de Historia del Derecho Español. N 6, Ed. Ministerio de Justicia y Boletín Oficial del Estado, Madrid, 1929.

SCIALOJA, V., Procedimiento civil romano. Ediciones Jurídicas Europa-América, Buenos Aires, 1954. 
SERRA DOMÍNGUEZ, M., "Notas al Anteproyecto de Actualización de la LEC". Justicia. Ed. Bosch, Barcelona, 1990.

TOMÁS TOMÁS, S., La administración concursal: claves para entender su actual régimen jurídico. Ed. Civitas-Thomson Reuters, Cizur Menor-Navarra, 2014.

TOMÁS Y VALIENTE, F., Manual de Historia del Derecho Español. Ed. Tecnos, Madrid, 2010.

TOMÉ PAULÉ, J., "La subasta judicial en el Derecho histórico español”. Boletín Mexicano de Derecho Comparado. Ed. Gobierno de México, México, 1975.

TALAMANCA, M., La ventita all'icanto nel proceso esecutivo romano. Vol. II. Ed. A. Giuffré, Milano, 1956.

TORRENT RUIZ, A.J., Manual de Derecho Privado Romano. Ed. Edifoser S.L., Zaragoza, 2002.

USÓN DUCH, L., Las subastas judiciales. Ed. Bosch, Barcelona, 1993.

VÁZQUEZ SOTELO, J.L. (Coord.), Comentarios a la Reforma de la Ley de Enjuiciamiento Civil. Ed. Reus, Madrid, 1985.

VELASCO PÉREZ, I. Las siete partidas del sabio rey Don Alonso. Ed. Maxtor, Madrid, 1843. 